\begin{tabular}{|c|c|c|}
\hline$\frac{5}{2}{ }_{1683}=5$ & THE JOURNAL OF WORLD INVESTMENT \& TRADE & $\begin{array}{l}\text { The Journal of } \\
\text { World }\end{array}$ \\
\hline B R I L L & $16(2015) 11-87$ & $\begin{array}{l}\text { Investment \& Trade } \\
\text { Law * Economics * Politics }\end{array}$ \\
\hline NIJHOF F & & brill.com/jwit \\
\hline
\end{tabular}

\title{
The Negotiations of the United Nations Code of Conduct on Transnational Corporations Experience and Lessons Learned
}

\author{
Karl P. Sauvant \\ Columbia Center on Sustainable Investment, Columbia Law School; \\ The Earth Institute, Columbia University, New York, USA \\ karlsauvant@gmail.com
}

\begin{abstract}
Many of the issues that are today part of the discussions surrounding international investment agreements were first dealt with when governments sought to negotiate a United Nations Code of Conduct on Transnational Corporations (and various related instruments) almost 40 years ago. The Code was meant to establish a multilateral framework to define, in a balanced manner, the rights and responsibilities of transnational corporations and host country governments in their relations with each other. This article looks at the origins of these negotiations, the underlying interest situations of the participating country groups, the experience of related negotiations, the actual negotiations of the Code, the reasons for the failure of the negotiations, the current situation, and factors driving change. The article concludes with lessons learned from the Code and related negotiations. These lessons may be of interest to current efforts to improve the international investment law and policy regime.
\end{abstract}

Resident Senior Fellow, Columbia Center on Sustainable Investment, a joint center of Columbia Law School and The Earth Institute at Columbia University, New York. He was the Founding Executive Director of the predecessor of that Center, the Vale Columbia Center on Sustainable International Investment. He joined the United Nations in 1973, assisting in the preparation of the first comprehensive report of that organization on Multinational Corporations in World Development (United Nations, 1973), before joining the newly created UNCTC as a junior professional as part of the nucleus of that Centre. He followed the United Nations Code negotiations from the beginning when he worked in UNCTC, and became directly involved in servicing them when he became the Chief of the Office of the Centre's Executive Director, 1985-1988 and when he was in charge of the Centre's research, 1988-2000 in UNCTC (and subsequently in UNCTAD's Investment Division). He retired in 2005 as the Director of that Division.

(C) KONINKLIJKE BRILL NV, LEIDEN, 2015 | DOI 10.1163/22119000-01601002 


\section{Keywords}

transnational corporations - foreign direct investment - regulation of transnational corporations - code of conduct - international investment regime

What rules should govern the behavior of transnational corporations (TNCs) in the countries in which they are established, and what rules should govern the treatment of these firms by the governments of host countries? This challenge has been on the international agenda since the end of World War II. However, it was only in the late 1970 s that negotiators began to formulate a comprehensive multilateral instrument, the United Nations Code of Conduct on Transnational Corporations, to tackle this challenge. In parallel to these negotiations (and subsequent to them), negotiations were also undertaken on specific aspects of the activities of TNCs, the principal private actors in international economic relations and important forces in individual economies. Although the Code negotiations - serviced by the United Nations Centre on Transnational Corporations (UNCTC) - came to naught, they crystallized the basic interest situations of the principal stakeholders and key issues associated with them, and they laid bare a number of the obstacles that governments seeking a multilateral investment instrument need to overcome. Many of these are still with us today and await an international solution.

I am grateful to a number of persons who were involved in one way or another in the negotiations of the United Nations Code (and related instruments) for kindly agreeing to be interviewed for this article and for providing very useful feedback on various drafts of this text (or parts of it): José Alvarez, Marino Baldi, Philippe Brusick, Clarke Ellis, Rainer Geiger, Peter Hansen, Juergen Kuehn, Miguel Marin-Bosch, Sotirios Mousouris, Sten Niklasson, Udo Papies, Stephen K Pursey, Klaus A Sahlgren, Farooq Sobhan, Marjan Svetličič, Kari Tapiola, and Guttorm Vik. I also gratefully acknowledge the very useful feedback from Kirstine Drew, Richard Eglin, John Evans, Michael Gestrin, Khalil Hamdani, Marie-France Houde, Gary Hufbauer, Joachim Karl, Roel Nieuwenkamp, Lauge Poulsen, Hassan Qaqaya, Lorraine Ruffing, John Ruggie, Zdzislaw Sadowski, Manfred Schekulin, Stephan W Schill, Lene Wendland, Christopher Wilkie, Zigniew Zimny and one anonymous peer reviewer. The helpful cooperation of Vasyl Chornyi, Harris Gleckman, Hamed el Kady, Robert Howard Kaplain, Hiroyuki Ota, Sergey Ripinski, Emily Sims, Elisabeth Tuerk, and Laura Zielinski is acknowledged. Finally, I want to thank Adrian P Torres, without whose help this text could not have been brought to fruition. An abbreviated excerpt of part of this article will be published in Khalil Hamdani and Lorraine Ruffing (eds), The United Nations Centre on Transnational Corporations: Corporate Conduct and the Public Interest (Routledge, forthcoming). Naturally, any errors are the author's.

THE JOURNAL OF WORLD INVESTMENT \& TRADE 16 (2015) 11-87 


\section{The Beginning}

UNCTC became operational on 1 November 1975 on the basis of a resolution of the United Nations Economic and Social Council, adopted in $1974 \cdot{ }^{1}$ It was a time when the international community had just 'discovered' how important TNCs (firms that control productive assets abroad) had become through their foreign direct investment (FDI). The trigger was ITT's interference in Chile's domestic policy, which eventually contributed to the overthrow of President Salvador Allende and politicized the issue further. ${ }^{2}$ President Allende drew attention to this interference in a speech in the General Assembly of the United Nations in 1972 and galvanized the international community to take action to address, and check, the 'economic power, political influence and corrupting action' of TNCs. ${ }^{3}$ But the issue was broader: TNCs were seen as having a substantial impact on individual national economies and international economic relations, and there was widespread suspicion that - given the global profitmaximizing strategies of TNCs versus the national development objectives of

1 Through Economic and Social Council (ECOSOC) resolution 1908 (LVII) of 2 August 1974. The Commission on Transnational Corporations was subsequently established through ECOSOC resolution 1913 (LVII) of 5 December 1974. See Sotirios Mousouris, 'Transnationals in the UN Spotlight: The Beginning' in Khalil Hamdani and Lorraine Ruffing (eds), The United Nations Centre on Transnational Corporations: Corporate Conduct and the Public Interest (Routledge, forthcoming) (Mousouris was one of the staff directly involved in the establishment of UNCTC and the Commission and became UNCTC's Assistant Director, Policy Analysis Division, 1975-1981; he was the Secretary of the Working Group on a Code of Conduct and, in that capacity, the principal UNCTC staff dealing with the Code negotiations); Khalil Hamdani, 'The UNCTC: Origins, History and Legacy' in Hamdani and Ruffing, ibid, ch 1. For a description and analysis of UNCTC's work (and, in some cases, subsequent work by UNCTAD) on international investment, see Hamdani and Ruffing, ibid; Tagi Sagafi-nejad in collaboration with John H. Dunning, The UN and Transnational Corporations: From Code of Conduct to Global Compact (Indiana University Press 2008); Sidney Dell, The United Nations and International Business (Duke University Press 1990) (Dell was UNCTC's Executive Director, 1983-1984); Theodore H Moran, 'The United Nations and Transnational Corporations: A review and a Perspective' (2009) 18 Transnational Corporations 91-112; John H Dunning, Seasons of a Scholar: Some Reflections of an International Business Economist (Edward Elgar 2009) passim; Torbjoern Fredriksson, 'Forty Years of UNCTAD Research on FDI' (2003) 12 Transantional Corporations $1-39$.

2 ITT's interference was subject to Hearings in the United States Congress, in the Church Committee; see <http://www.aarclibrary.org/publib/contents/church/contents_church_reports _vol7.htm> accessed 15 September 2014.

3 See address Salvador Allende, President of the Republic of Chile, UN General Assembly, Twenty-Seventh Session, 4 December 1972, UN Doc A/PV.2096.

THE JOURNAL OF WORLD INVESTMENT \& TRADE 16 (2015) 11-87 
governments - this impact was negative in terms of the distribution of benefits and the ability of indigenous firms to grow and prosper. ${ }^{4}$

Around the same time, most developing countries had emerged from colonialism, consolidated their independence, had become members of the United Nations, and began to assert themselves in international fora. A number of them also discovered their bargaining power, especially the oil exporting countries organized in Organization of the Petroleum Exporting Countries (OPEC), reflected in the actions they took in 1973. Other developing countries possessing natural resources in demand in world markets also thought that they could assert themselves by organizing themselves in producer cartels. This possibility was discussed in an influential article by Fred Bergsten, published in Foreign Policy in 1974, entitled 'One, two, many OPECs ... ? The threat is real.'5 Nationalizations reached their peak in the early $1970 s .{ }^{6}$ Moreover, developing countries sought to enhance their bargaining position through importsubstitution strategies and by cooperating more in the economic area, in the framework of the concept of 'economic cooperation among developing countries.'7 Developing countries saw themselves in the ascendancy.

4 Annexes to the report of the second session of the Commission on Transnational Corporations contain lists of concerns regarding the activities of these firms as they were seen at that time; many of these concerns were subsequently addressed in the Code negotiations. See Commission on Transnational Corporations, 'Report on the Second Session 1-12 March 1976' (E/5782 ECOSOC Official Records: Sixty-First Session, Supplement No 5). For a broader discussion, see eg Richard J Barnet and Ronald E Mueller, Global Reach: The Power of the Multinational Corporations (Simon and Schuster 1974).

5 Foreign Policy (Spring 1974) 84-90.

6 See Stephen J Kobrin, 'Expropriation as an Attempt to Control Foreign Firms in LDCs: Trends from 1960 to 1979 ' (1984) 28 ISQ 329-334.

7 The non-aligned countries, as well as the Group of 77 , organized numerous meetings to enhance economic cooperation among them. See Odette Jankowitsch and Karl P Sauvant (eds), The Third World Without Superpowers: The Collected Documents of the Non-Aligned Countries (OCEANA 1978-1993) vols 12.; Karl P Sauvant and Joachim W Mueller (eds), The Third World without Superpowers, Second Series: The Group of 77 (OCEANA 1981-1995) vols 20. However, as shown by subsequent developments, there is a difference between intentions and implementation. For a critical discussion, see Marjan Svetlicic, 'Economic Cooperation Among Developing Countries: Business Activity and/or Politics?' (1986) 2 Development \& South-South Cooperation 49-66 (Svetlicic was (1977-1991) Senior Research Associate at the Research Centre for Cooperation with Developing Countries, Ljubljana, during the time the Code was negotiated; he represented Yugoslavia on the Commission during 1978-1984 and, throughout the period, was consulted by the government in his capacity as expert on MNEs and FDI). 
The confluence of these factors was reflected in the drive of the developing countries, supported by the socialist countries, to establish a New International Economic Order (NIEO). The two NIEO resolutions, adopted during the Sixth Special Session of the United Nations General Assembly in ${ }_{1974}{ }^{8}$ made explicit reference to the need to regulate $\mathrm{TNCs},{ }^{9}$ as did the Charter of

8 The Declaration on the Establishment of a New International Economic Order asked for, among other things, the " $[\mathrm{r}$ ] egulation and supervision of the activities of transnational corporations by taking measures in the interest of the national economies of the countries where such transnational corporations operate on the basis of the full sovereignty of those countries.' See <http://www.un.org/en/ga/search/view_doc.asp?symbol=A/RES/ 3201(S-VI) > accessed 15 September 2014. The Programme of Action on the Establishment of a New International Economic Order stated that '[a]ll efforts should be made to formulate, adopt and implement an international code of conduct for transnational corporations.' See <http://www.un.org/en/ga/search/view_doc.asp?symbol=A/RES/3202(S-VI)> accessed 15 September 2014. Both NIEO resolutions were adopted without a vote; however, a number of developed countries registered strong reservations. It should be noted, though, that there was always a difference between the rhetoric of governments in international organizations and what governments did at the national level: countries continued to admit FDI, although they could have unilaterally restricted it.

9 When the United Nations began work in this area, the firms involved were called 'multinational corporations.' See eg United Nations, Multinational Corporations in World Development (United Nations, 1973) (the first major report on this subject by the United Nations). The Group of Eminent Persons, in its report, noted in a footnote: 'There is general agreement in the Group that the word "enterprise" should be substituted for corporations, and a strong feeling that the word transnational would better convey the notion that these firms operate from their home bases across national borders.' See 'Report of the Group of Eminent Persons to Study the Impact of Multinational Corporations on Development and on International Relations' in United Nations, The Impact of Multinational Corporations on Development and International Relations (United Nations 1974) 25. However, the Report of the Group on Eminent Person continued to use 'multinational corporation' in conformity with Economic and Social Council resolution 1721 (LIII) ibid.

When delegates debated the issue in the United Nations, three points were made: $(1)$ the description 'multinational' was seen to imply that the firms involved were owned or controlled by citizens of various nations, while in reality the overwhelming majority of them were owned and controlled by citizens of one country, the home country; (2) the socialist countries preferred the term 'corporation' as opposed to 'enterprise', as the latter would have included their firms controlling assets abroad, while they did not have firms that were incorporated, and hence would not be covered, in their interpretation, by the term 'multinational/ transnational corporation' (interview with Kari Tapiola Special Assistant to the Executive Director (Klaus A Sahlgren) in UNCTC (1976-1978); General Secretary of the Trade Union Advisory Committee to the OECD (TUAC), 1978-1985; and Expert-Adviser (1978-1990), while International Affairs Director of the Confederation of Finnish Trade Unions

THE JOURNAL OF WORLD INVESTMENT \& TRADE 16 (2015) 11-87 
Economic Rights and Duties of States, adopted by vote in the same year. ${ }^{10}$ It was in this context that the Commission on Transnational Corporations (comprising representatives of governments) and UNCTC (as the secretariat of the Commission) were established, and the drive began to deal with TNCs and their FDI at the international level. ${ }^{11}$ Not surprisingly (given the context),

(1985-1996) and in these capacities participated in the Code negotiations) and Stephen Pursey (who was Head of the ICFTU Economic and Policy Department when he participated in the Code negotiations), 8 January 2014); (3) at that time, the Andean Pact had adopted an agreement that foresaw the creation of 'Andean multinational enterprises', owned and controlled by various members of the Andean Pact countries (see Andean Code on Multinational Enterprises and the Regulations with regard to Subregional Capital (1972) 11 International Legal Materials 357-372). To take these considerations into account and to avoid any confusion between the 'good' Andean Pact enterprises and firms headquartered elsewhere, delegates decided to change the terminology from 'multinational corporation' to 'transnational corporation': this term has been used in the United Nations since then. However, this change in terminology did not take into account that a number of firms operating transnationally are not incorporated and that, therefore, a more accurate label would have been 'transnational enterprise.' The non-aligned countries, in their own work on these enterprises, used the term 'multinational enterprise' and sought to promote the establishment of such firms as joint ventures among themselves, partly in the framework of a 'self-reliance' concept. See eg 'Report on a Meeting of the Group of Fisheries Experts of Non-Aligned Countries on the Establishment of Multinational Fisheries Enterprises', (Colombo 15-16 July 1982) (exploring the possibility of establishing joint ventures in this area); see Jankowitsch and Sauvant (n 7) vol X $410-412$.

See Charter of Economic Rights and Duties of States (A/RES/29/3281) <http://www .un.org/en/ga/search/view_doc.asp?symbol=A/RES/3281(XXIX)\&Lang=E\&Area $=$ RESOLUTION $>$ accessed 29 September 2014. Six developed countries voted against this resolution, and ten countries abstained.

This is not to say that this issue had not been on the international agenda before: immediately after World War II, an effort had been made to address some aspects of international investment in the framework of the aborted Havana Charter for an International Trade Organization. See also General Assembly resolution No 1803 (XVII) (discussing 'permanent sovereignty over natural resources', which addressed investment issues in the context of natural resources) <http://daccess-dds-ny.un.org/doc/RESOLUTION/GEN/ NRo/193/11/PDF/NR019311.pdf?OpenElement> accessed 15 September 2014. For a brief review of earlier efforts of establishing international investment rules, see Stephan W Schill, The Multilateralization of International Investment Law (CUP 2009).

The non-aligned countries, too, sought to coordinate their work vis-à-vis TNCs, especially through the establishment of a center of their own focused on these enterprises. See 'Report of the Coordinating Countries in the Field of Transnational Corporations' (3 to 7 September 1979) (submitted to the 1979 Havana Summit and reporting that a sufficient number of countries had approved the statutes of the Information Center on

THE JOURNAL OF WORLD INVESTMENT \& TRADE 16 (2015) 11-87 
this drive focused on controlling TNCs, at least as far as developing countries were concerned, as well as a number of developed countries. However, developed countries also had a separate interest, namely to legitimize $\mathrm{TNCs}^{12}-$ in fact to 'tame'13 them through legal means - in light of the world-wide criticism that was leveled against these firms, not only in developing countries, where they were seen as agents of imperialism by some, ${ }^{14}$ but also in developed

Transnational Corporations and that it should start operations immediately, located in Havana); Jankowitsch and Sauvant (n 7) vol V 307-308. However, the original idea for the establishment of the Non-Aligned Countries Information Center on Transnational Corporations did not materialize since only 14 countries ratified the proposed Statute of the Center, while 20 countries should have done so. See Marjan Svetlicic and Matija Rojec, Transnational Corporations and Direct Foreign Investment (Research Center for Cooperation with Developing Countries, Ljubljana and Zimbabwe Institute of Development Studies, Harare 1987) 143. Instead, at the Zimbabwe Summit of the NonAligned Countries ( 1 to 5 October 1984) it was decided in the Summit's 'Economic Declaration' that 'the work relating to transnational corporations and private foreign investment be for the present undertaken by the Research and Information System (RIS) of non-aligned and other developing countries until such time as a final decision is taken in regard to the Information Center.' See Jankowitsch and Sauvant (n 7) vol XI 409. The RIS subsequently began operations, located in New Delhi. The business community, too, recognized that it needed to react and, accordingly, adopted its own (voluntary) guidelines. See International Chamber of Commerce, Guidelines for International Investment (ICC 1972) (updating its 'International Code of Fair Treatment for Foreign Investments', which had been drawn up by the ICC's Committees on Foreign Investments and Foreign Establishments and approved by the ICC's Quebec Congress in June 1949; contained in UNCTAD, International Investment Instruments: A Compendium (UNCTAD 1996) vol III 273-278). Another update was undertaken in May 2012 <http://www.iccwbo.org/Advocacy-Codes-and-Rules/Document-centre /2012/2012-ICC-Guidelines-for-International-Investment/> accessed 29 September 2014. The 1972 version dealt with the following subjects: investment policies, ownership and management, finance, fiscal policies, legal framework, labour policies, technology, and commercial policies. These guidelines - which were of course available to the Code negotiators - also signaled what international business was prepared to accept.

To quote Juergen Kuehn (who was Director in the Ministry of Economics of Germany and, in this capacity, the chief Code negotiator on behalf of the Federal Republic of Germany, 1983-1986). Communication by him (24 February 2014) (on file with the author). However, this objective receeded in the background in the course of the negotiations. See eg Allende (n 3) in which, among other things, he lamented that TNCs: withdraw wealth from the Third World; are 'rudely transforming traditional practices in international trade, the transfer of technology, the transmission of resources among nations, and labour relations'; interfere in 'the fundamental political, economic and military decisions' of sovereign States; and 'are not only undermining the genuine interests of the 
ones. ${ }^{15}$ An international code, supported by all countries, would have blunted this criticism. Overall, it was recognized that, since TNCs operated in a global context, any effort at regulation needed to be global as well.

This effort, then, proceeded on two avenues: the negotiation of issuespecific agreements and the negotiation of a comprehensive multilateral instrument. As to the former, a number of issue-specific instruments were indeed successfully negotiated during the next few years, especially the Tripartite Declaration of Principles Concerning Multinational Enterprises and Social Policy, agreed upon in the International Labour Organization (ILO); ${ }^{16}$ The Set of Multilaterally Agreed Equitable Principles and Rules for the Control of Restrictive Business Practices, agreed upon in the United Nations Conference on Trade and Development (UNCTAD); ${ }^{17}$ and the Declaration on International Investment and Multinational Enterprises, agreed upon in the Organisation for Economic Co-operation and Development (OECD). ${ }^{18}$ In addition, negotiations took place on codes of conduct on breast-milk substitutes, ${ }^{19}$ consumer protection, ${ }^{20}$ the transfer of technology, ${ }^{21}$ and illicit

developing countries, but their overwhelming and uncontrolled force is felt too in the industrialized countries in which they are based.'

15 See eg United States Senate, Committee on Foreign Relations, Subcommittee on Multinational Corporations, $93^{\text {rd }}$ Congress, $1^{\text {st }}$ Session, The International Telephone and Telegraph Company and Chile 1970-1971 (Government Printing Office 1973) (the extensive hearings in the United States on outward FDI and especially the activities of ITT in Chile). In Europe, Jean-Jacques Schreiber's Le defi américain (Éditions Denoël 1968) received wide attention.

16 ILO, Tripartite Declaration of Principles Concerning Multinational Enterprises and Social Policy, adopted by the Governing Body of the ILO on 16 November 1977.

17 UNCTAD, The Set of Multilaterally Agreed Equitable Principles and Rules for the Control of Restrictive Business Practices (A/RES/35/63 5 December 1980); see UN Doc TD/RBP/ CONF/10/Rev.1 (1981).

See OECD, International Investment and Multinational Enterprises (OECD 1976). For the most recent version, see <http://www.oecd.org/daf/inv/investment-policy/oecddeclaration anddecisions.htm> accessed 15 September 2014. As of late 2014, all 34 OECD member countries and 12 non-OECD members had adhered to the Declaration. WHO, International Code of Marketing of Breast-milk Substitutes (1981). Guidelines for Consumer Protection (A/RES/39/248 9 April 1985).

Negotiations (between 1976 and 1985) of the Draft International Code of Conduct on the Transfer of Technology were not completed <http://stdev.unctad.org/compendium/ documents/totcode\%20.html> accessed 29 September 2014. For a discussion, see Surendra Patel, Pedro Roffe and Abdulqawi Yusuf (eds), International Technology Transfer: The Origins and Aftermath of the United Nations Negotiations on a Draft Code of Conduct (Kluwer International 2000).

THE JOURNAL OF WORLD INVESTMENT \& TRADE 16 (2015) 11-87 
payments ${ }^{22} .{ }^{23}$ But the centerpiece - and umbrella - was meant to be a comprehensive (multilateral) United Nations Code of Conduct on Transnational Corporations, defining the entirety of relations between governments and TNCs. The umbrella nature of the Code was reflected, in terms of architecture, in the fact that the draft included cross-references to a number of the instruments just mentioned, making these separate instruments in a sense 'chapters' of the United Nations Code. ${ }^{24}$

Accordingly, the first session of the Commission on Transnational Corporations in $1975^{25}$ established a preliminary program of work, giving the

22 For a brief history and the text of the Draft International Agreement on Illicit Payments, see $<$ http://unctad.org/Sections/dite_tobedeleted/iia/docs/compendium/en/9\%2ovolume \%201.pdf> accessed 15 September 2014. The draft was put before the General Assembly in 1979, but the General Assembly took no action. The negotiations of this instrument, proposed by the United States, were serviced by UNCTC. But since neither the developing countries, nor other developed countries were strongly supportive of these negotiations, this effort fizzled out in the United Nations at that time (The CTC Reporter regularly covered progress in the negotiations). However, the issue was later addressed in the OECD and led to the adoption of the 'Convention on Combating Bribery of Foreign Public Officials in International Business Transactions', which entered into force on 15 February 1999 <http://www.oecd.org/daf/anti-bribery/ConvCombatBribery_ENG.pdf> accessed 29 September 2014. The issue returned to the United Nations where eventually the United Nations Convention against Corruption was adopted by the General Assembly on 31 October 2003 (it entered into force on 14 December $2005<\mathrm{http}$ // www.unodc .org/documents/treaties/UNCAC/Publications/Convention/o8-50026_E.pdf> accessed 29 September 2014.

23 The Commission also began work in the area of international accounting, partly with a view toward devising international reporting standards to allow a more transparent assessment of the activities of TNCs across jurisdictions. When the Commission eventually established the Intergovernmental Working Group of Experts on International Standards of Accounting and Reporting (through ECOSOC resolution 1982/67), its mandate did not include the authorization to set standards, but instead was reduced to promoting comparability among national standards. See Lorraine Ruffing, 'Transparency and Disclosure: Lifting the Veil from Corporate Reporting' in Hamdani and Ruffing ( $\mathrm{n}$ 1).

The draft Code included cross-references to the International Code of Conduct on the Transfer of Technology (which, at that time, was negotiated in UNCTAD), the Set of Multilaterally Agreed Equitable Priniciples and Rules for the Control of Restrictive Business Practices (also negotiated in UNCTAD), the International Agreement on Illicit Payments (negotiated at that time in the United Nations in New York), and the ILO Tripartite Declaration of Principles Concerning Multinational Enterprises and Social Policy.

25 The Commision held a total of 20 sessions. The first session took place in New York, from 17 to 28 March 1975, and the last session was held in Geneva from 2 to 11 May 1994. The last

THE JOURNAL OF WORLD INVESTMENT \& TRADE 16 (2015) 11-87 
Code of Conduct the highest priority. ${ }^{26}$ The Commission's second session (1-12 March 1976) reaffirmed this program of work and stated that the objective of the United Nations Code (and UNCTC) should be, among other things, ' $\mathrm{t}$ ] $\mathrm{o}$ secure effective international arrangements for the operation of transnational corporations designed to promote their contribution to national developmental goals and world economic growth while controlling and eliminating any negative effects. ${ }^{27}$ The Commission's second session also established the Intergovernmental Working Group on a Code of Conduct to formulate the Code. The objective was to adopt an instrument by consensus.

\section{Different Underlying Interest Situations}

The zeitgeist clearly reflected the desire of the great majority of countries to control TNCs. However, not all countries had the same priorities when the Commission mandated negotiations during its second session in 1976. Thus, it is necessary to examine the underlying interest situations of the three principal country groups - that of developing countries, socialist countries and developed countries - on the basis of which the negotiations were undertaken.

At the time that the Code negotiations began, virtually all developing countries were overwhelmingly recipients of FDI, i.e., host countries: their outward FDI amounted to about $2 \%$ of world FDI outflows between 1980-1985, averaging little more than USD 1 billion during that period. ${ }^{28}$ The basic interest of developing countries was therefore to minimize any negative effects of the engagement of TNCs in their territories, be they economic, social or political (see the ITT incident). At the same time, developing countries were not

session of the Commission on Transantional Corporations took place after the UNCTC had been abolished in 1992 and the staff of the Centre had been transferred to Geneva and integrated into UNCTAD in 1993, to continue work on MNEs and TNCs in that organization see Hamdani and Ruffing (n 1). It recommended to ECOSOC that the Commission be integrated into UNCTAD's institutioal machinery. See Commission on Transnational Corporations, 'Report on the Twentieth Session (2-11 May 1994)' (E/1994/32 ECOSOC Official Records Supplement No 12).

26

28 See 'Official Records of the Economic and Social Council' (E/5655, E/C.10/6. 59th Session, Supplement No 12). For the genesis of the United Nations' work on MNEs, see Sotirios Mousouris in Hamdani and Ruffing ( $\mathrm{n} 1)$. See Official Records (n 4) para 6.

See United Nations, World Investment Report 1992: Transnational Corporations as Engines of Growth (United Nations 1992) table I 1 and annex table 1.

THE JOURNAL OF WORLD INVESTMENT \& TRADE 16 (2015) 11-87 
interested in any multilateral disciplines that could tie their hands in relation to the treatment of foreign investors in their (in many cases newly achieved) sovereign jurisdictions. Rather, they preferred national regulation of TNCs, be it to deal with corporate abuses, to promote their own development or to pursue other public policy objectives, supported by international instruments. For that, they needed to maintain their national policy space in the investment area. Moreover, since they barely had any outward FDI flows, they had no particular interest in protecting their investors abroad. Hence, their basic interest was to arrive at an instrument that would prescribe multilateral rules of behavior for transnational corporations (headquartered in a relatively small number of developed countries).

During the most active phase of the Code negotiations, virtually no socialist country permitted inward FDI, and their outward FDI was miniscule. ${ }^{29}$ For them, to quote Klaus A. Sahlgren, TNCs were 'poisonous flowers on the dungheap of a dying capitalism. ${ }^{30}$ Moreover, to the extent that they had their own TNCs, they insisted that these enterprises should not be covered by the Code as they were subject to direct government control. Eventually, as discussed below, this led to difficulties in the context of the definition of TNCs, as the Western countries insisted that no difference should be made between them and privately owned firms. For the socialist countries (in line with the position of the Soviet Union), the negotiations were largely a political exercise that gave them the opportunity to embarrass the Western countries, although eventually broader interests came into play. ${ }^{31}$ Beyond that, they adopted a defensive position, namely to protect their own interest of not having their firms covered by

29 For a discussion of outward FDI flows from the socialist countries, see Carl H McMillan, Multinationals from the Second World: Growth of Foreign Investment by Soviet and East European Enterprises (St Martin's Press 1987). Yugoslavia at that time was the only socialist country that had, since 1967 , a joint venture law, but the level of inward FDI was very low.

30 See Klaus A Sahlgren, 'Scenes from my UN journey' in Martti Ahtisaari (ed), Finns in the United Nations (Finnish UN Association 1996) 205. Sahlgren was UNCTC's first Executive Director, serving from $1975^{-1982}$, and the highest-ranking UNCTC staff responsible for the Code negotiations.

31 To quote Udo Papies (who participated, as a member of the delegation of the German Democratic Republic, in the Code negotiations between 1981-1989) 'At the beginning, the socialist countries regarded the debate about TNCs and the negotiations of a Code as a conflict between developed and developing countries. In the course of the negotiations, however, they developed a broader interest in the Code as an instrument to reflect equality and mutual benefit in international economic relations.' Communication by Udo Papies, 17 March 2014 (on file with the author).

THE JOURNAL OF WORLD INVESTMENT \& TRADE 16 (2015) 11-87 
the Code; and they supported the developing countries. China maintained a low profile during the Code negotiations. ${ }^{32}$

For developed countries, the situation was more complex. They were, worldwide, the principal home and host countries. However, as far as FDI flows among developed countries were concerned (the bulk of their outflows and inflows), these were covered by instruments negotiated in the framework of the OECD. In particular, they could rely on the 1961 Code of Liberalisation of Capital Movements (even though it allowed for exceptions). Such code provided for 'a balanced framework for countries progressively to remove barriers to the movement of capital, while providing flexibility to cope with situations of economic and financial instability. ${ }^{\prime 3}$ This instrument was further supplemented in 1976 by the OECD Declaration on International Investment and Multinational Enterprises, containing voluntary Guidelines for TNCs as well as decisions addressed to member governments concerning national treatment, conflicting requirements and international investment incentives and disincentives, ${ }^{34}$ and by the global ILO Tripartite Declaration of Principles Concerning Multinational Enterprises and Social Policy, containing voluntary guidelines in the area of social policy. ${ }^{35}$ Developed countries could also draw on a network of Friendship, Commerce and Navigation Treaties that protected not only trade but also investment; these treaties were, sometimes, as with respect to the United States, directly enforceable in local states courts. ${ }^{36}$

With these instruments, developed countries had a regime in place that reflected their principal interest: the protection of investments of their firms abroad, which involves, in particular, the proper treatment of investors and investments in terms of national treatment, most-favored-nation treatment, fair and equitable treatment (interpreted as 'minimum standard'), prompt, adequate and effective compensation upon expropriation, and the right to

32 But this is not to say that there were not intensive inter-ministerial discussions in Beijing on this matter.

See <http://www.oecd.org/daf/inv/investment-policy/CapitalMovements_WebEnglish .pdf $>$ accessed 15 September 2014.

OECD (n 18).

ILO (n 16).

See eg Treaty of Friendship, Commerce and Navigation Between the United States of America and Japan (signed 2 April 1953) (providing that Japanese nationals residing in the United States may not be subjected to payment of taxes 'more burdensome than those borne by' United States nationals, and according Japan 'most favored nation' status.) See eg Japan Line Ltd v Los Angeles County, 441 US 434 (1979) (holding California state property tax on Japanese shipping affiliates unconstitutional since it results in multiple taxation).

THE JOURNAL OF WORLD INVESTMENT \& TRADE 16 (2015) 11-87 
repatriate profits. Increasingly, national treatment at the pre-establishment phase of an investment was added to this list. ${ }^{37}$ This regime provided developed countries with access for their firms to the markets of other developed countries (at that time the world's most attractive markets) and, through the well functioning, impartial judiciaries in developed countries, access to national dispute settlement if disputes should arise on account of inappropriate treatment of their investors or investments. Moreover, as their regulatory and judicial regimes could also deal with corporate misbehavior and since they had, in any event, the OECD Guidelines and the ILO Tripartite Declaration, developed countries had no pressing interest in establishing multilateral disciplines for (mostly their) TNCs.

While developed countries had adequate protection in place for investments among themselves, as well mechanisms to deal with corporate abuses, they thought ${ }^{38}$ that protection was not guaranteed for the treatment of the investments of their firms in developing countries. ${ }^{39}$ This was particularly the case in light of the uncertainties after decolonization, the number of nationalizations, ${ }^{40}$ the often weak and not necessarily impartial judiciaries in many developing countries, and the reluctance of developing countries to tie their hands through international investment rules. The basic interest of the developed countries was therefore focused on prescribing multilateral standards of behavior for how host country governments should treat foreign investors, in the interest of protecting their firms from undue interference by governments in the operations of TNCs. For that, they needed to circumscribe the policy space of host countries, ${ }^{41}$ i.e., developing

37 Among developed countries, the right of establishment was only accepted in 1984, through an amendment of the Code of Liberalisation of Capital Movements <http://www.oecd .org/daf/inv/investment-policy/CapitalMovements_WebEnglish.pdf > accessed 15 September 2014, and <http://www.oecd.org/investment/investment-policy/theexperienceoftheoecd withtheoecdcodeofliberalisationofcapital movements.htm> accessed 24 August 2014 Interview with Rainer Geiger (who was, at the time of the Code negotiations (1977-1991), Head of Division, Enterprise and Consumer Affairs, OECD and participated in the Code negotiations as an observer for the OECD; he also serviced the OECD Informal Contact Group on the Code, in the framework of which member countries coordinated their position on the Code (1977-1981) (6 November 2013).

39 Access to markets was, at that time, not yet a major issue.

$40 \quad \operatorname{Kobrin}(\mathrm{n} 6)$.

41 In principle, there might also have been a question of the policy space of home countries. This became an issue about 35 years later when emerging market firms - a number of them being state-owned enterprises - became important players in the world FDI

THE JOURNAL OF WORLD INVESTMENT \& TRADE 16 (2015) 11-87 
countries. ${ }^{42}$ While a number of developed countries had started to negotiate (beginning in 1959) bilateral investment treaties (BITs) with developing countries and such treaties reaffirmed customary international (investment) law (and the International Centre for Settlement of Investment Disputes (ICSID) became available in $1966^{43}$ ), the number of BITs was still relatively small (131 by 1980), ${ }^{44}$ compared to the great number of BITs that would be ratified later. The BITs of that day were still relatively weak, ${ }^{45}$ and the United States had barely begun negotiating such treaties (although, by the mid-1980s, the United States

market, and the question of (especially emerging market) home country government support for the outward FDI by their state-owned enterprises was put on the international agenda. See Karl P Sauvant and others, 'Trends in FDI, Home Country Measures and Competitive Neutrality' in Andrea Bjorklund (ed), YB Intl Inves L \& Pol'y 2013-2014 (OUP 2014) ch 1.

42 At the time of the United Nations Code negotiations, the applicability of BITs to developed countries did not mean much, as there was little FDI from emerging markets into developed countries.

The first case arose before ICSID in 1972 (Holiday Inns SA and others $v$ Morocco, ICSID Case No ARB/72/1), but the number of cases did not increase rapidly until the early 2000 ; see $<$ http://icsid.worldbank.org/ICSID/FrontServlet?requestType=ICSIDDocRH\&action Val=ShowDocument $\&$ CaseLoadStatistics $=$ True $\&$ language=English42 $>$ accessed 29 September 2014. The establishment of the Multilateral Investment Guarantee Agency (MIGA) in 1988 is also relevant. Its members agreed to allow the Agency to provide coverage against defined risks and, by issuing host country approvals and supporting a project through their representatives at the Board, agreed that MIGA can protect against those risks in their country. In doing so, they do not necessarily agree that they will be held to any particular standard of behavior with regard to the investment. Article 18 on subrogation provides that MIGA will be subrogated to the rights of the investor without specifying the source or nature of those rights. Importantly, in the context of this article, Annex II of the convention provides for arbitration between MIGA and a member in the event of a dispute between them. Paragraph (g) of art 4 of the annex provides the bases on which the tribunal will decide the scope, and that list includes 'applicable rules of international law' as well as domestic law and other sources. Arguably this constitutes acceptance of international law, at least vis-à-vis MIGA. Still, they provided a fall-back position for developed countries in case they could not reach a satisfactory agreement at the multilateral level.

As José E Álvarez (who participated in some of the Code negotiation sessions as part of the United States delegation in his capacity as an attorney adviser in the United States Department of State) stated: 'the typical treaty...combined relatively weak investment protections with an ineffectual investor-state dispute settlement clause'; see José E Álvarez, 'The Once and Future Foreign Investment Regime' in Mahnoush H Arsanjani and others (eds), Looking to the Future: Essays on International Law in Honor of W. Michael Reisman (Martinus Nijoff 2010) 607, 615.

THE JOURNAL OF WORLD INVESTMENT \& TRADE 16 (2015) 11-87 
BITs program was in full swing). ${ }^{46}$ Hence, the basic interest of developed countries was to arrive at a code of conduct for the governments of host countries (especially developing countries) in the international investment area.

Moreover, the interest situation of these three groups of countries needs to be seen against the background of the nascent stage of international investment law at the time the negotiations began. Jeswald W. Salacuse and Nicholas P. Sullivan captured that status succinctly: 'foreign investors who sought the protection of international investment law encountered an ephemeral structure consisting largely of scattered treaty provisions, a few questionable customs, and contested general principles of law. ${ }^{47}$ This situation of rudimentary international investment law - consisting mostly of customary international (investment) law - was challenged by developing countries, including in a number of United Nations General Assembly resolutions (e.g., on the NIEO and the Charter on Economic Rights and Duties of States). ${ }^{48}$ This made it all the more important for developed countries to prevent the erosion of what they considered established customary international law standards for the treatment of foreign investors and, if anything, protect and affirm, if not strengthen, these standards.

These different underlying interests of the various country groups were reflected in the title of the instrument to be negotiated, namely a Code of Conduct on Transnational Corporations (emphasis added) - leaving it open what such a Code would eventually cover. ${ }^{49}$

46 For the evolution of the United States BITs effort, see Kenneth J Vandevelde, Bilateral Investment Treaties: History, Policy, and Interpretation (OUP 2010); see also José E Álvarez, The Public International Law Regime Governing International Investment (Martinus Nijhoff 2009) ch II.

47 Jeswald W Salacuse and Nicholas P Sullivan, 'Do BITs Really Work? An Evaluation of Bilateral Investment Treaties and Their Grand Bargain' (2005) 46 Harvard Intl L J 68.

48 There is a debate about the legal standing of resolutions by the General Assembly of the United Nations. Stephen Schwebel, for example, seems broadly to embrace the normative effect of such resolutions, although this effect may depend on the extent to which such resolutions enjoy wide support; see Stephen Schwebel, 'The Effect of Resolutions of the UN General Assembly on Customary International Law' (1979) 73 ASIL Proceedings 301-309. Others, however, question the capacity of General Assembly resolutions to contribute to customary international law; see eg Anthony D'Amato, 'Trashing Customary International Law' (1987) 81 AJIL 101-106. For a discussion, see José E Álvarez, International Organizations as Law-makers (OUP 2005) 159-163 and Thomas M Franck and Mark M Munansangu, The New International Economic Order: International Law in the Making? (UNITAR 1982).

49 Note that the Programme of Action on the Estalishment of a New International Economic Order had referred to a 'code of conduct for transnational corporations' (n 8) (emphasis

THE JOURNAL OF WORLD INVESTMENT \& TRADE 16 (2015) 11-87 
In principle, it should have been possible to bridge the different starting positions of developed and developing countries. ${ }^{50}$ There was a certain degree of overlapping interest, even if for different reasons, to take action: developed countries wanted to legitimize the outward investment of their firms (vis-à-vis their trade unions and developing countries) and strengthen the protection of their TNCs, while developing countries wanted to have an instrument that would help them to deal with any negative effects of TNC investments. In a number of countries, there was pressure from trade unions and media. And, together, this created the political will to move forward.

The key challenge was, therefore, to reconcile the different basic interest situations of home and host countries and the objectives that flowed from them in relation to the role of international investment law and the responsibilities of governments and firms. As home countries, governments want to maximize protection for their firms investing abroad, and facilitate their operations, i.e., they seek the constraints that international investment law imposes on the treatment of foreign investors and their investments, and they have reservations regarding the constraints that guidelines impose on certain activities of TNCs. As host countries, governments seek to preserve a maximum amount of national policy space to be able to pursue public policy objectives, ${ }^{51}$ i.e., they seek to preserve the flexibility that the national regulatory regime provides for the treatment of foreign investors and their investments (including to regulate corporate behavior they consider undesirable and to attract investment they

added). For the same reason of balance, the name of UNCTC was the 'United Nations Center on Transnational Corporations' (emphasis added) - it was neither 'for' nor 'against' these entities; rather, its approach was to help governements to minimize the negative effects and maximize the positive effects of the activities of TNCs. The perception of governments and the public at large of the work of the United Nations was, however, dominated by the often anti-TNC rhetoric in the Commission on Transnational Corporations, in which developing countries (supported by the socialist countries) often clashed with developed countries. The secretariat (ie, UNCTC) that prepared documents for the Commission and undertook a wide range of activities, on the other hand, had to serve all groups of countries, and its approach was therefore more balanced - even though the sympathy of many members of the staff was with the developing countries.

For an example of someone who was skeptical that agreement could be reached, see Jürgen Kühn, 'Developing Countries Rethink Their Approach to Foreign Investment' (1984) 19 Intereconomics 280 ('In view of the opposing economic interests and the differences in historical and political developments, it may be that a worldwide project to establish effective rules for investment protection will forever be a[n] utopia') (Kühn was one of the Code negotiators).

51 The challenge is, of course, to distinguish between legitimate public policy objectives, as opposed to other objectives (eg protectionist ones).

THE JOURNAL OF WORLD INVESTMENT \& TRADE 16 (2015) 11-87 
considered desirable), and they support, especially if they are relatively weak, the constraints that guidelines impose on certain activities of TNCs.

The challenge was - and remains - to bridge these different basic interest situations and find the right balance between how these various objectives can be accommodated, as reflected in the relative respect accorded to national laws and regulations on the one hand and international investment law on the other, in relation to both, the treatment of foreign investors and their investments and the responsibilities of investors and governments. Any comprehensive multilateral instrument on international investment needs to take these underlying tensions into account.

\section{The Experience with the OECD and ILO Declarations and the UNCTAD Set}

Before turning to the United Nations Code negotiations themselves, it is necessary to look at the experience of the negotiations of the OECD ${ }^{52}$ and $\mathrm{ILO}^{53}$ Declarations and the negotiations of the UNCTAD Restrictive Business

52 For a discussion of the OECD Declaration and, in particular, the OECD Guidelines, see among others (apart from the literature referenced elsewhere in this article) Roger Blanpain, The OECD Guidelines or Multinational Enterprises and Labour Relations, 1976-1979: Experience and Review (Kluwer 1979); Claes Hägg, 'The OECD Guidelines for Multinational Enterprises: A Critical Analysis' (1984) 3:1 Journal of Business Ethics 71-76; Jacques Rojot, 'The 1984 Revision of the OECD Guidelines for Multinational Enterprises' (1985) 23:3 British Journal of Industrial Relations 279-397; Stephen Tully, 'The 2000 Review of the OECD Guidelines for Multinational Enterprises' (2001) 50:2 Intl \& Comp L Q 394-404; Gefion Schuler, 'Effective Governance Through Decntralized Soft Implementation: The OECD Guidelines for Multinational Enterprises' (2008) 9:11 German L J 1753-1778; Sarah Fick Vendzules, 'The Struggle for Legitimacy in Environmental Standards Systems: The OECD Guidelines for Multinational Enterprises' (2010) 21:3 Colorado J Intl Env L \& Pol'y 451-489; Joshua S Yang and others, 'A Question of Balance: Addressing the Public Health Impacts of Mutlinational Enteprises in the OECD Guidelines for Multinational Enterprises' (2012) 7:10 Global Public Health 1045-1061.

53 For a discussion of the ILO Declaration, see among others (apart from the literature referenced elsewhere in this article), Roger Blanpain (ed), Multinational Enterprises and the Social Challenges of the XXIst Century (Kluwer Law International 200o); Janelle M Diller, 'Social Conduct in Transnational Enterprise Operations: The Role of the International Labour Organization' ibid, 17-28; Jernej Letnar Cernic, 'Corporate Responsibility for Human Rights: Analyzing the ILO Tripartite Declaration of Principles Concerning Multinational Enterprises and Social Policy' (2009) 6:1 Miskolc J Intl L 24-34.

THE JOURNAL OF WORLD INVESTMENT \& TRADE 16 (2015) 11-87 
Practices Set. ${ }^{54}$ This is because these instruments were negotiated in the shadow of the Code discussions, they were intimately linked to them and they foreshadowed a number of the difficulties that the Code negotiations were to experience.

For one, the OECD Declaration was only possible because it involved a quidpro-quo: Guidelines for $\mathrm{MNEs}^{55}$ versus one decision dealing with follow-up procedures and two dealing with the treatment of investors and investments by governments, among which the national treatment instrument was particularly important. ${ }^{56}$ The voluntary nature of the Guidelines reflects an OECD

54 For a discussion of the UNCTAD Set see Stuart E Benson, 'The UN Code on Restrictive Business Practices: An International Antitrust Code is Born' (1981) 30 The American University L Rev; Colin R Greenhill, 'UNCTAD: Control of Restrictive Business Practices' (1978) 12:1 JWT 67-74; Thomas B Atkeson and David G Gill, 'The UNCTAD Restrictive Business Practices Code: A Step in the North-South Dialogue' (1981) 15:1 Intl L 1-23; Stuart E Benson, 'UN Conference on Restrictive Business Practices' (1980) 74:2 AJIL 451-453; Furnish, 'A Transnational Approach to Restrictive Business Practices' (1970) 4 Intl L 32227; David G Gill, 'The UNCTAD Restrictive Business Practices Code: A Code for Competition' (1979) 13 Intl L 607; Sagafi-Nejad and Dunning (n 1) 127-36; Lee E Preston and Duane Windsor, The Rules of the Game in the Global Economy: Policy Regimes for International Business (Kluwer Academic Publishers 1997) 79-81.

The OECD Guidelines, as adopted in 1976, contained the following chapters: General policies; Disclosure of information; Competition; Financing; Taxation; Employment and industrial relations; and Science and Technology. Later, the following chapters were added: Concepts and Principles; Human Rights; Environment; Combatting Bribery, Bribe Solicitation and Extortion; and Consumer Interests. In addition, text in individual chapters was changed from time to time to update it in light of factual developments and new insights as to the desirability of international directives, and often congruent with national laws. Moreover, the financing chapter was dropped, apparently because the guideline could not be formulated concretely enough to be of practical use as a guideline without intervening too much into the operational activities of firms. I am grateful to Marino Baldi (who was Ambassador of Switzerland, Deputy Director, Federal Office of External Economic Affairs, and Chair of the Western European and Others Group in the Code negotiations (1983-1993); he was also a participant in the negotiations of the Restrictive Business Practices Set) for these explanations. Communication by Marino Baldi, 20 March 2014 (on file with the author).

56

The three decisions adopted in 1976 were 'Decision of the Council on Inter-Governmental Consultation Procedures on the Guidelines for Multinational Enterprises'; 'Decision of the Council on National Treatment'; and 'Decision of the Council on International Investment Incentives and Disincentives'. See <http://www.oecd.org/daf/inv/ mne/50024800.pdf $>$ accessed 15 September 2014. In 1984, a Decision on conflicting requirements was added to the Declaration; see <http://www.oecd.org/daf/inv/ mne/50024913.pdf> accessed 15 September 2014.

THE JOURNAL OF WORLD INVESTMENT \& TRADE 16 (2015) 11-87 
approach according to which international standards for government behavior may, but need not, be legally binding, while international recommendations for the behavior of non-governmental actors should not. Accordingly, the substantive parts of the Guidelines, addressed to MNEs operating in or from adhering countries, are voluntary, ${ }^{57}$ but the commitment of adhering countries to implement and promote them (e.g., by setting up National Contact Points), which took the form of a separate Council Decision, is not. ${ }^{58}$

The ILO Tripartite Declaration, ${ }^{59}$ for its part, was also voluntary, was addressed jointly to governments, employers' and workers' organizations and TNCs and applied regardless of the nature of ownership (i.e., public, private or mixed), ${ }^{60}$ reflecting the tripartite character of the ILO in their home and host

$57 \quad$ Although individual subjects may well be regulated in a binding manner at the national level of adhering countries and may also be addressed in other international instruments. The OECD describes the Guidelines as 'the only multilaterally agreed comprehensive code of responsible business conduct that governments have committed to promoting.' See OECD, OECD Guidelines for Multinational Enterprises (OECD 2011) 3.

Another example for this approach is the OECD Convention on Combating Bribery of Foreign Public Officials in International Business Transactions (n 22). However, Article 1 of the Convention obliges signatories to make bribery of foreign officials a criminal offence. It should also be noted that, in the OECD context, the distinction between 'voluntary' and 'binding' is not always clear-cut as observance in both cases is mainly achieved through peer review/pressure. I am grateful to Manfred Schekulin, Chair of the OECD's Investment Committee, for pointing this out to me. Communication by Manfred Schekulin, 7 March 2014 (on file with the author).

59 The ILO Declaration, as adopted in 1977, contained the following headings: GENERAL POLICIES; EMPLOYMENT, Employment promotion, Equality of opportunity and treatment, Security of employment; TRAINING, CONDITIONS OF WORK AND LIFE, Wages, benefits and conditions of work, Safety and health; INDUSTRIAL RELATIONS, Freedom of association and the right to organise, Collective bargaining, Consultation, Examination of grievances, and Settlement of industrial disputes. A list of international labor conventions and recommendations referred to in the Declaration was contained in an addendum, which was amended in 1987, 1995, 2000, and 2006. Furthermore, in 1986, the Governing Body of the International Labour Office adopted a 'Procedure for the examination of disputes concerning the application of the Tripartite Declaration of Principles Concerning Multinational Enterprises and Social Policy by means of interpretation of its provisions.' See <http://www.ilo.org/empent/Publications/WCMS_094386/lang--en/index .htm $>$ accessed 15 September 2014 .

60 They are also sought to reflect good practices for national firms. See Hans Guenter, 'The Tripartite Declaration of Priniciples (ILO): Standards and Follow-up' in Norbert Horn (ed), Legal Problems of Codes of Conduct for Multinational Enterprises (Kluwer 1980) 156-157. See also Nordic Tripartite Seminar on Multinational Enterprises and Social Policy, Summary of Proceedings (Helsinki, Finland 26 and 27 September 1989).

THE JOURNAL OF WORLD INVESTMENT \& TRADE 16 (2015) 11-87 
countries. This Declaration focuses only on one specific part of the activities of TNCs, namely social policy. It was clear that the Tripartite Declaration's implementation depended on the active cooperation of the business community, given the tripartite structure of the ILO. The Tripartite Declaration was therefore a more limited instrument.

Finally, in the case of the UNCTAD Restrictive Business Practices Set, a voluntary instrument as well, there was also a trade off: developing countries sought to control especially restrictive business practices related to trade by TNCs and abuses of dominant positions by these firms, as these were seen as hindering their development. The developed countries saw the Set as a step toward dismantling state and para-statal monopolies (along with their vertical restrictive business practices) in developing countries (and later also in transition economies), improving in this manner access to the markets of the countries involved and obtaining wider acceptance of their conception of competition policy. ${ }^{61}$

Second, the two Declarations were negotiated and adopted in very little time, less than one-and-a-half years, ${ }^{62}$ and the UNCTAD Set was negotiated in a little bit more than a year. ${ }^{63}$ This shows what is possible if self-interest, pressure and political will are present. Particularly relevant here is that trade unions in developed countries had employment and industrial relations concerns, including about the off-shoring of jobs and the impact of the rise of international production networks on their collective bargaining positions; accordingly, they put pressure on friendly (especially social-democratic) governments to take action. The adoption of the two Declarations, therefore, reduced the pressure on developed countries' governments from one of their important constituencies, and the adoption of the Restrictive Business Practices Set took care of one of the concerns of the developing countries. The adoption of the Declarations and the Set also represented a 'pre-emptive

61 Interviews with Philippe Brusick (who took part in the preparatory process and then the two negotiating conferences on UNCTAD's Restrictive Business Practices Set, before he became Head of UNCTAD's Competition and Consumer Protection Branch, from 1985 to 2006) and Hassan Qaqaya (26 January 2014). Multinational Enterprises' (1977) 2 The CTC Reporter 28, 30. on Restrictive Business Practices, which held two negotiating sessions in NovemberDecember 1979 and April 1980. The negotiations were completed in 1980, during the Administration of President Jimmy Carter, and the Code was adopted by the General Assembly at the end of 1980 .

THE JOURNAL OF WORLD INVESTMENT \& TRADE 16 (2015) 11-87 
strike' ${ }^{64}$ against the United Nations Code, as it signaled that the developed countries, in which the overwhelming number of TNCs were based, had recognized that something needed to be done to legitimize the role of these firms in international economic relations and national economies, neutralizing in this manner at least some of the pressure of trade unions at the multilateral level.

Third, and accordingly, the OECD Guidelines, the ILO Tripartite Declaration and the UNCTAD Set showed the limit of what developed countries were willing to accept as guiding their firms. ${ }^{65}$ In that sense, the two instruments represented the coordinated bargaining platform of the developed countries for the guidelines aspect of the United Nations Code negotiations. ${ }^{66}$ Agreement on these three instruments was also facilitated by the fact that they were largely in line with the domestic regulatory framework of most OECD members. If anything, developed countries were prepared to go further amongst themselves (as far as the OECD Guidelines were concerned), and be more precise in this respect than they would have wanted to be within a global context, as the OECD countries were largely like-minded, facilitating the definition of a common self interest and reducing the fear that provisions would be interpreted in an unacceptable manner. ${ }^{67}$

Fourth, this like-mindedness is also reflected in the OECD Guidelines' relatively strong implementation mechanism, which was strengthened over time. The OECD Committee on International Investment and Multinational Enterprises (CIME), which later merged with the Capital Movement Committee in charge of the Liberalisation Code to form the Investment Committee, has

64 As Kari Tapiola, 'The Heritage of the UN Code of Conduct' in Hamdani and Ruffing (n 1 ) described the OECD Guidelines.

65 Tapiola ibid, described the ILO Tripartite Declaration as a 'universal and more detailed rendering of the principles that had some months earlier been established within the OECD' to be 'used where it was more specific - and, of course, it was valid outside the industrialized country area.'

66 The OECD had established an Informal Contact Group on the Code, to allow member countries to coordinate their position on the United Nations Code. At the time of the Code negotiations, when Sten Niklasson (the Chair of the Intergovernmental Working Group on a Code of Conduct during the duration that that Group met) was Vice-Chair of the OECD Committee on International Investment and Multinational Enterprises, he deliberately abstained from intervening in the internal OECD coordination on the Code. The OECD Informal Contact Group on the Code was serviced by Rainer Geiger of the OECD secretariat. Communication by Rainer Geiger (8 January 2014) (on file with the author).

67 Communication by Marino Baldi (9 January 2014) (on file with the author).

THE JOURNAL OF WORLD INVESTMENT \& TRADE 16 (2015) 11-87 
the mandate, through its Working Party on the OECD Guidelines for Multinational Enterprises, ${ }^{68}$ to monitor the implementation of the Guidelines and to clarify the Guidelines in the light of concrete cases/issues brought to its attention. Although the Committee cannot pronounce itself on the behavior of individual enterprises, it can take cases as illustrations of issues that need a clarification of the meaning of the Guidelines, thereby giving strength to the implementation of the instrument. ${ }^{69}$

In 1979, furthermore, it was decided to establish National Contact Points in adherent countries to '[contribute] to the resolution of issues that arise from the alleged non-observance of the guidelines in specific instances. ${ }^{70}$ This introduced another layer of institutions to deal with grievances related to TNCs. The Guidelines' implementation mechanism was strengthened further as a result of the 2000 review by adding procedural guidelines for the handling of specific instances by the National Contact Points and improving the linkage between the National Contact Points and the Committee on International Investment and Multinational Enterprises. In particular, the review provided that issues could be raised before the National Contact Points by any interested party, including non-governmental organizations and even individuals. ${ }^{71}$ The 2011 review of the Guidelines established indicative timelines for the National Contact Points for issues brought to their attention. It provided that they needed to act in a manner that is impartial, predictable and equitable, and that statements needed to be issued on cases when these are closed. Most importantly, consultative status with the Investment Committee was extended to OECD Watch, the OECD Investment Committee's recognized representative of civil society organizations. ${ }^{72}$ The latest improvement came in 2013 when a Working Party on Responsible Business Conduct was established to,

68 That Working Party was eventually discontinued, replaced in 2013 by the Working Party on Responsible Business Conduct. decision (n 56). It applies however only to the procedure, not the outcome (eg clarifications and recommendations, which are not binding). The clarification process was developed starting in 1977, ie, almost immediately after the adoption of the Guidelines as a result of cases submitted, and this practice was formalized by the 1979 Review and incorporated in a revised Council decision C (79) 143. See <http://mneguidelines.oecd.org/ncps> accessed 15 September 2014.

71 See OECD, Guidelines for Multinational Enterprises, revised 27 June $2000<$ http://www .oecd.org/investment/mne/1922428.pdf> accessed 29 September 2014. OECD 2011 (n 57). 
among other things, 'assist in enhancing the effectiveness of the Guidelines' in the context of a pro-active agenda. ${ }^{73}$

The ILO Tripartite Declaration's implementation mechanism, for its part, provided a forum for discussion of matters related to follow-up ${ }^{74}$ and interpretation. ${ }^{75}$ The Declaration's original text did not foresee a procedure for interpretation in the event of a disagreement among the parties as to the meaning of the text, but it was agreed among the parties that one would be adopted later on. ${ }^{76}$ In 1981 , then, a procedure was instituted in this respect, ${ }^{77}$ which was elaborated in an updated procedure in 1986 that is still applicable today. ${ }^{78}$ The

73 OECD, Reviewing the Mandates of the Subsidiary Bodies of the Investment Committee (DAF/INV(2013)15/REV1 15 November 2013). The Chair of the Working group is Roel Nieuwenkamp (Netherlands).

74 Initially through a Committee of ILO's Governing Body and, then, in the context of an ILO organizational reform (in 1993), the Sub-Committee of the Committee on Legal Affairs and International Labour Standards. In 2010, most committees were abolished; subjects have since been discussed and acted upon on the basis of a plenary agenda item of the ILO's Governing Body.

75 As Tapiola pointed out, the negotiations of the ILO Tripartite Declaration had taken place largely on the basis of the OECD Guidelines text. This meant 'that the ILO instrument can continue to be used in the OECD context in the cases where it is more specific.' Moreover, ' $\mathrm{t}$ ] he follow-up procedures of both instruments have over the years not produced contradictory conclusions, and thus the danger of "forum shopping" (or trying to get a more favourable opinion) has been avoided.' Kari Tapiola, 'The OECD Guidelines for Multinational Enterprises and Other Global Instruments for Corporate Responsibility' (Presentation to the Roundtable on Global Instruments OECD, Paris, 19 June 2001) 5, 6. See also Tapiola (n 64).

This was confirmed in the 1979 OECD review report, which stated: 'Wherever [the ILO] principles refer to the behavior expected from enterprises, they parallel the OECD Guidelines and do not conflict with them. They can, therefore, be of use in relation to the OECD Guidelines to the extent they are of a greater degree of elaboration.' However, the review report continued to emphasize: 'It must, however, be born in mind that the responsibilities for the follow-up procedures of the OECD Guidelines and of the ILO Declaration are institutionally separate.' See OECD, International Investment and Multinational Enterprises: Review of the 1976 Declaration and Decisions (OECD 1979) para 30.

76 Interview with Kari Tapiola (12 March 2014).

77 See Part IV of the Procedures adopted by the Governing Body at its 214th Session (November 1980); see Official Bulletin, vol LXIV (1981), Series A, No 1, pp. 990.

78 See the 1986 ILO, 'Procedure for the Examination of Disputes Concerning the Application of the Tripartite Declaration of Principles Concerning Multinational Enterprises and Social Policy by Means of Interpretation of its Provisions' 17 <http://www.ilo.org/empent/ Publications/WCMS_094386/lang--en/index.htm> accessed 29 September 2014. For a discussion of the procedure, in the framework of a review of the Tripartite Declaration's

THE JOURNAL OF WORLD INVESTMENT \& TRADE 16 (2015) 11-87 
Procedure is however quite restrictive, requiring among other things that the relevant (tripartite) committee needed to decide unanimously (after consultations) whether a request was receivable. ${ }^{79}$ Follow-up also included the conduct of surveys (eventually discontinued), ${ }^{80}$ the addition of cross-references to new ILO Declarations (e.g., on core labor standards) and the active promotion of the instrument. Eventually (in 2010), the ILO Helpdesk for Business and International Labour Standards was established through which firms (and others) can obtain information pertaining to international labor standards in general, including those contained in the Tripartite Declaration.

The UNCTAD Restrictive Business Practices Set also foresaw an implementation mechanism, the Intergovernmental Group of Experts on Restrictive Business Practices (in 2000 renamed the Intergovernmental Group of Experts on Competition Law and Policy), meeting annually, and the quinquennial review conference; these provided a platform for discussions and consultations. However, these intergovernmental mechanisms were not used to amend or elaborate the Set. The intergovernmental machinery also did not issue

working during its first ten years, see Jacques Lemoine, 'The ILO Tripartite Declaration: Ten Years After' (1988) 25 The CTC Reporter 22-28.

However, if agreement could not be reached, a request could be referred to the full committee for unanimous decision ( $\mathrm{n} 78$ ). The unanimity requirement was maintained following the shift to the Committee from the Subcommittee of ILO's Governing Body. The revised procedure adopted in 1986 provided that 'The Officers of the Committee on Multinational Enterprises shall decide unanimously after consultations ...' (para 4 in the pertinent part of 1986 version adopted to replace the 1980 procedures ( $\mathrm{n} 78)$ ). The 2010 reform and revision of the Governing Body's rules changed the Committee on Multinational Enterprises into a Section of the Policy Segment of the Governing Body, and these take place in plenary.

The surveys of the effect given to the ILO Declaration, completed at the request of the Governing Body, were based on the Governing Body's requests for voluntary replies by member states to a questionnaire. Governments, employers and workers could separately or jointly submit their responses. Eight surveys were conducted since the Declaration was adopted, and the analytic as well as country-specific profiles were reported to the Governing Body; the results, in turn, informed the ILO priorities in work with member states. For the results of the seventh survey (covering 100 member countries) see $<$ http:// www.ilo.org/public/english/standards/relm/gb/docs/gb28o/mne-1-1.htm> and <http:// www.ilo.org/public/english/standards/relm/gb/docs/gb28o/pdf/mne-1-2.pdf $>$ accessed 15 September 2014. The last (2005) survey was the eighth; see <http://www.ilo.org/public/ english/standards/relm/gb/docs/gb294/pdf/mne-1-2.pdf > accessed 15 September 2014. The ILO's current approach comprises the establishment of an information-gathering system that replaces the periodic surveys < http://www.ilo.org/gb/GBSessions/GB320/ pol/WCMS_236168/lang--en/index.htm> accessed 15 September 2014.

THE JOURNAL OF WORLD INVESTMENT \& TRADE 16 (2015) 11-87 
clarifications or interpret the Set. In fact, the instrument explicitly provided that ' $[\mathrm{i}] \mathrm{n}$ the performance of its functions, neither the Intergovernmental Group nor its subsidiary organs shall act like a tribunal or otherwise pass judgement on the activities or conduct of individual Governments or of individual enterprises in connexion with a specific business transaction.' ${ }^{81}$ It probably would have been too difficult to utilize these various mechanisms in a multilateral context to strengthen the Set. It was only through the active work of the UNCTAD Secretariat (which included the preparation of a model competition law, peer reviews of the experience of individual countries and capacity building in developing countries) that the Set became widely known and led to the establishment of competition authorities in emerging markets. ${ }^{82}$

Fifth, the implementation mechanism, importantly, not only allows governments to raise issues in the competent committee, but also trade unions and business. While this possibility is inherent in the tripartite structure of the ILO, it was (and is) particularly important in the OECD. There, the Trade Union Advisory Committee (TUAC) and, in principle, the Business and Industry Advisory Committee (BIAC), ${ }^{83}$ can bring cases to the attention of the OECD's committee structure, for the purpose of clarifying the Guidelines. As already mentioned, the 2011 review of the Guidelines gave this right also to nongovernmental organizations, which had already received the right, through the

81 See UNCTAD Set (n 17 ) Section G (ii) 4.

82 For a review of the activities related to the Set, see eg 'Report of the Thirteenth Session of the Intergovernmental Group of Experts on Competition Policy' (TD/B/C.I/CLP/25, 8-10 July 2013). In 2001, the WTO noted that about 80 countries, including some 50 developing countries and transition economies, had adopted competition laws; in 2007, the World Bank counted 106 competetion authorities, including in six regional integration group bodies. See R S Khemani, Competition Policy and Promotion of Investment, Economic Growth and Poverty Alleviation in Least Developed Countries (2007) FIAS Occasional Paper 19. The work of the Secretariat was helped by the increased attention that governments gave to competition issues, including in the context of the European Union's Single Market, the demise of the centrally planned economies and widespread privatizations.

83 Apparently, only once, in January 2012, did a firm raise an issue in relation to another firm, involving the activities of an Australian TNC operating in Chile in the mining and quarrying sector. The Chilean firm alleged that the Australian TNC had breached Guidelines provisions relating to human rights; employment and industrial relations; and consumer interests. The Chilean National Contact Point is undertaking an initial assessment of this complaint. See <http://mneguidelines.oecd.org/database/searchresults/?hf=10\&b=0\&sl $=$ mne \&q=!H!all\&s=desc $($ mne_datereceived $)>$ accessed 15 September 2014. On the other hand, no case has been raised by one NGO against another, although this could theoretically be done if the NGO in question can be considered as an enterprise.

THE JOURNAL OF WORLD INVESTMENT \& TRADE 16 (2015) 11-87 
2000 review, to raise cases with the National Contact Points. ${ }^{84}$ This provision combined with the existence of the implementation machinery for the Guidelines - proved to be crucial: until the end of 1999, the majority of the 30 cases/issues brought for clarification were raised by trade unions (trade unions brought 19 cases and governments brought 11 cases), ${ }^{85}$ beginning immediately after the adoption of the Guidelines. ${ }^{86}$ Between the beginning of 2000 and the end of 2013, around 300 cases had been submitted to the National Contact Points, virtually all by non-governmental organizations and trade unions. ${ }^{87}$

The trade unions and, subsequently, non-governmental organizations, made the voluntary Guidelines a 'living' instrument, together with an actively managed committee structure.

In the case of the ILO Tripartite Declaration, more than 50 requests for interpretation of the instrument's provisions had been submitted until 1994, but 'only a handful of them could be taken up, since the others related to

84 Non-governmental organizations, as grouped in the OECD Watch, are also invited, alongside BIAC and TUAC, to stakeholder consultations; they participated actively in the 2000 and 2011 reviews.

85 See OECD, 'Previous Requests for Clarification of the OECD Guidelines for Multinational Enterprises', DAFFE/IME/WPG/RD(2001) 4 (16 March 2001). The first case involved a United States company, Raytheon, that had closed a subsidiary in Belgium without respecting Begian law on employee notice and compensation. See Roger Blanpain, The Badger Case and the OECD Guidelines for Multinational Enterprises (Kluwer Law International 1977). Of the 30 cases until the end of 1999, the top three provisions for which clarification were sought were paras 6, 9 and 3 under 'Employment and Industrial Relations.' In 1977, the first opportunity to submit cases, TUAC submitted 11 cases and governments 2 cases.

87 It is difficult to determine the exact number of cases submitted to National Contact Points, as not all of them report cases to the OECD Secretariat. For the number of cases recorded by the OECD (n 83). OECD Watch has its own reporting <http://oecdwatch.org/cases/ statistics $>$ accessed 29 September 2014. For TUAC < http://www.tuacoecdmneguidelines.org/ statistics.asp > accessed 15 September 2014; <http://www.tuacoecdmneguidelines .org/Docs/TradeUnionGuide.pdf> accessed 15 September 2014. The three subjects on the basis of which cases were brought since 2000 were, in the case of trade unions: paras $1(\mathrm{~b})$ (Right to collective bargaining); 1(a) (Right to organise); and 6 (Provide information on changes in operations with major employment effects) under Employment and Industrial Relations. In the case of non-governmental organizations, the distribution was: General Policies; Employment and Industrial Relations; and Environment. One case was brought by an individual. If those who raised cases are not satisfied with the response they received from a National Contact Point, they can request that the OECD Investment Committee take up the matter.

THE JOURNAL OF WORLD INVESTMENT \& TRADE 16 (2015) 11-87 
matters that, in principle, could be dealt with more appropriately under the follow-up mechanisms of certain ILO conventions.'88 Again, trade unions were the driving force.

Finally, in the case of the UNCTAD Set, only governments are allowed to raise issues in the competent intergovernmental body - probably the principal reason why the application of the Set took place primarily through the Secretariat's work.

None of these instruments, however, foresees penalties for non-observancea limitation of any voluntary instrument.

Sixth, as evidenced by subsequent developments, after the OECD Guidelines had been adopted and there were interested stakeholders who made use of them, it was possible to build on the text and strengthen it, in an incremental process through a number of reviews. ${ }^{89}$ In fact, in subsequent reviews, chapters were added to the Guidelines, their scope was greatly expanded to cover supply chains and the implementation mechanism was strengthened, including by further opening it up to civil society. Although agreement on a follow-up mechanism was reached only later in the case of the ILO Tripartite Declaration, it was strengthened by further references to newer conventions and recommendations. In the case of the UNCTAD Set, on the other hand, no further strengthening of the instrument took place at the intergovernmental level for fear of unwinding what has already been achieved. ${ }^{90}$ As previously mentioned, all further work on the Set took place through the work of the Secretariat, with the main success having been the adoption of national competition laws.

Since the OECD Declaration was adopted before the negotiations on the United Nations Code had begun, the ILO Declaration during the first year of the Code negotiations and the UNCTAD Set during the most active phase of the Code negotiations, these instruments set the stage and provided background for the Code negotiations. Also, importantly, at least two of these three instruments assuaged the concerns of a key constituency supporting global guidelines: trade unions.

88 Presentation by a representative of the ILO Secretariat at the 20 th session of the Commission on Transnational Corporations; see Commission on Transnational Corporations (n 25). In particular, freedom-of-association cases, the most frequent type of cases that arose under the Tripartite Declaration, were taken up in the Committee on Freedom of Association, a committee that trade unions did not want to weaken; interview with Kari Tapiola (24 January 2014). According to Tapiola, interpretation requests have by and large been dormant since the first half of the 1990s. Communication by Kari Tapiola (3 May 2014) (on file with the author).

$89 \quad$ Reviews took place in 1979, 1984, 1991, 2000, and 2011.

90 Communication by Philippe Brusick (5July 2014) (on file with the author).

THE JOURNAL OF WORLD INVESTMENT \& TRADE 16 (2015) 11-87 


\section{The Code Negotiations}

The negotiations in the Intergovernmental Working Group on a Code of Conduct began 10-15 January 1977, during the first of its 17 sessions; ${ }^{91}$ they were serviced by UNCTC as the secretariat. ${ }^{92}$ All sessions were chaired by Sten Niklasson (Sweden), who managed to create, according to Sahlgren, 'a very good ambience, almost one of camaraderie, while maintaining a high

91 The Working Group met as follows: 1st session, 10-15January 1977; 2nd session, 18 April-4 May 1977; 3rd session, 6-14 February 1978; 4th session, 20-31 March 1978; 5 th session, 18-29 September 1978; 6th session, 8-19 January 1979; 7th session, 12-23 March 1979; 8th session, 7-18 January 1980; 9th session, 17-23 March 1979; 1oth session, 12-21 May 1980 ; 11th session, $13^{-24}$ October 1980 ; 12 th session, $5^{-23}$ January $1981 ; 13$ th session, $6-17$ April 1981; 14th session, 18-29 May 1981; 15th session, 4-15 January 1982; 16th session, 1-12 March 1982; 17th session, 10-21 May 1982; see <http://lib-unique.un.org/DPI/DHL/ unique.nsf?Open $>$ accessed 15 September 2014. At its $17^{\text {th }}$ session, the Working Group submitted its final report (E/C.10/1982/6) to the Commission on Transnational Corporations, meeting for the eighth time, 30 August-10 September 1982; that report contained the draft Code of Conduct on Transnational Corporations, as negotiated by the Working Group (ie, with brackets indicating unresolved issues and alternative texts).

UNCTC prepared numerous documents in support of the Code negotiations. See eg UNCTC, Transnational Corporations: Issues Involved in the Formulation of a Code of Conduct (United Nations 1976); United Nations, Transnational Corporations: Materials Relevant to the Formulation of a Code of Conduct (United Nations 1977); Patrick Robinson, The Question of a Reference to International Obligations in the United Nations Code of Conduct on Transnational Corporations (UNCTC 1986), UNCTC Current Studies, Series A, No 1; Detlev Vagts, The Question of a Reference to International Obligations in the United Nations Code of Conduct on Transnational Corporations: A Different View (UNCTC 1986), UNCTC Current Studies, Series A, No 2; UNCTC, Bilateral Investment Treaties (United Nations 1988); UNCTC, Key Concepts in International Investment Arrangements and Their Relevance to Negotiations on International Transactions in Services (UNCTC 1990), UNCTC Current Studies, Series A, No 13; and UNCTC, The New Code Environment (UNCTC 1990), UNCTC Current Studies, Series A, No 16. In addition to these published studies, available from the Sales Section of the United Nations, UNCTC also prepared many official documents dealing with Code issues for the consideration of the Working Group, the Commission and the special sessions of the Commission. Many of them are listed in The CTC Reporter, which also reported regularly about the progress of the negotiations. Issue no 12 (summer 1982) reproduces the text of the Working Group on the Code, as submitted to the Commission on Transantional Corporations $3-4,23-26$, as well as a number of short articles dealing with various aspects of the negotiations, from different perspectives. Issue no 29 (spring 1990) also contains a number of essays of particular relevance to the Code negotiations.

THE JOURNAL OF WORLD INVESTMENT \& TRADE 16 (2015) 11-87 
intellectual standard, ${ }^{93}$ although, not surprisingly, the atmosphere became more precarious and testy later during the negotiations. ${ }^{94}$

There is no need to rehearse in detail what had and had not been agreed upon during the negotiations, as others have written about it. ${ }^{95}$ Suffice it to say

93 Communication by Klaus A Sahlgren (13January 2014) (on file with the author). The Chair of the Working Group also made special efforts to forge agreement. As Sten Niklasson recollects: 'a number of hurdles were overcome by invitations to a few key delegates to a remote castle in Sweden, where everyone was locked up until compromise solutions were struck.' Communication by Sten Niklasson (9 February 2014) (on file with the author).

Guttorm Vik (who represented Norway in the Code negotiations from the early 1980 os to the early 1990s; he was at that time Senior Counselor and subsequently Head of Division, Counselor of Embassy (in the United Nations Mission of Norway in New York) and Deputy Director General in the Norwegian Foreign Service; he also represented the Nordic countries in the Commission for two terms) characterized the atmosphere of the Code discussions in the Commission and ECOSOC as follows: 'some "Young Turks" from the $\mathrm{G}_{77} \ldots$ seemed more interested in riding their ideological hobbyhorses than in reaching reasonable compromises and promoting mutual interests.' See Guttorm Vik, 'A UN Code of Conduct for Transnational Corporations: A Good Idea Whose Time had not Come' in Hamdani and Ruffing (n 1). In contrast to the often politicized atmosphere in the Commission, the tenor of negotiations in the Working Group was usually more pragmatic.

94 The Working Group reported on progress to the regular sessions of the Commission; for that purpose, the Commission had a permanent agenda item, although its wording changed over time, and eventually did no longer refer to the Code. More specifically, beginning with its third session in 1977 and until 1981, the Commission's agenda included an item entitled 'Work Related To The Formulation Of A Code Of Conduct: Report Of The Intergovernmental Working Group On A Code Of Conduct' in which the progress on the negotiations was discussed. After the work of the Working Group had ended, and at the Commission's eighth's session in 1982, the agenda item became 'Work Related To The Formulation Of A Code Of Conduct' and 'Work Related To The Formulation Of A Code Of Conduct On Transnational Corporations' in 1983. In 1984, the agenda item became 'Work Related To The Formulation Of A Code Of Conduct On Transnational Corporations And Other International Arrangements And Agreements'. In 1992, the agenda item was listed as, 'International Arrangements And Agreements Relating To Transnational Corporations.' In 1993, it was 'International, Regional And Bilateral Arrangements And Agreements Relating To Transnational Corporations'. In 1994, it became 'International Arrangements And Agreements Relating To Foreign Direct Investment And Transnational Corporations, Incuding Guidelines And Other Instruments'.

95 Apart from the Code literature referenced elsewhere here, the literature includes Samuel K B Asante, 'Doctrinal Differences on the Code of Conduct' in Hamdani and Ruffing (n 1); for a more detailed discussion, see Asante's 'The Concept of the Good Corporate Citizen in International Business' (1989) 1 ICSID Rev Foreign Investment L J 1-38, and his

THE JOURNAL OF WORLD INVESTMENT \& TRADE 16 (2015) 11-87 
that the negotiations - covering a wide range of issues (box 1) - faced the immediate difficulty of having to deal with a very complex range of issues without having had the benefit of being able to draw on extensive preparations. Moreover, negotiators could not rely on substantial experience of their own: apart from the relative small number of BITs that had been signed by the time the Code negotiations began (and that typically were very short and did not involve real negotiations) and the focused discussions on expropriation and permanent sovereignty over natural resources in the context of the Charter of Economic Rights and Duties of States and the NIEO resolutions, this was the first time that negotiators dealt comprehensively with international investment and the firms undertaking such investment. The negotiations were therefore an exercise of 'learning by doing,' slowing down the process. To quote Sten Niklasson, the Chair of the Working Group: 'As it played out in reality, most things happened more or less simultaneously and in great haste. Many countries came to meetings of the Commission and the Working Group having but

'The January 1986 Reconvened Special Session' (1986) 21 The CTC Reporter 14-19; Stephan Coonrod, 'The United Nations Code of Conduct for [sic] Transnational Corporations' (1977) 18 Harvard Intl L J 273-307; International Bar Association, Codes of Conduct for Transnational Corporations: Signals of Public Expectations (International Bar Association, Section on Business Law 1981); A A Fatouros, 'The UN Code of Conduct of [sic] Transnational Corporations: Problems of interpretation and Implementation' in Seymour J Rubin and Gary Clyde Hufbauer (eds), Emerging Standards of International Trade and Investment (Rowman \& Allanheld 1983) 101-118; Horn (n 6o); Carsten-Thomas Ebenroth and Joachim Karl, Code of Conduct: Ansätze zur vertraglichen Gestaltung internationaler Investitionen (Universitaets Verlag 1987); Emily F Carasco and Jang Singh, The United Nations Code of Conduct on Transnational Corporations: Some Unresolved Issues (University of Windsor 1988); Daniel B Magraw, 'United Nations ECOSOC Draft Code of Conduct on Transnational Corporations' in Stephen Zamora and Ronald A Brand (eds), Basic Documents of International Economic Law (Commerce Clearing House 1990) 533; A A Fatouros (ed), Transnational Corporations: The International Legal Framework (Routledge 1994); Ruth Rosenbaum, 'In Whose Interest? A Global Code of Conduct for Corporations' in Oliver Williams (ed), Global Codes of Conduct: An Idea whose Time has Come (University of Notre Dame Press 2000) 211-220; Cynthia Day Wallace, The Multinational Enterprise and Legal Control: Host State Sovereignty in an Era of Economic Globalization (Nijhoff 2002); and Khalil Hamdani, 'Code of Conduct: Attempting an International Regulatory Framework' in Hamdani and Ruffing (n 1). For UNCTC's summary of the outstanding issues, see 'Completion of the formulation of the Code of Conduct on Transnational Corporations: Information paper on the negotiations'. Note by the Secretariat (E/C.10/1983/S/2, 4 January 1983). For a detailed analysis of the outstanding issues regarding the treatment provisions in the Code, see 'Outstanding Issues in the Draft Code of Conduct on Transnational Corporations' (E/C.10/1985/S/2, 22 May 1985).

THE JOURNAL OF WORLD INVESTMENT \& TRADE 16 (2015) 11-87 
the faintest idea of the practical issues to be tackled. ${ }^{96}$ Clearly, circumstances were very difficult, and were further accentuated by the fact that a relatively large number of countries were involved.

In the beginning, negotiations focused on the guidelines, while 'issues related to the treatment [of investors] and the legal nature [of the instrument] were not seriously discussed in the early years. ${ }^{97}$ But it became clear in the course of the negotiations in the Working Group that, unless the Code would be a balanced instrument covering rules for both TNC behavior and government treatment of such firms, the negotiations could well collapse. ${ }^{98}$

\section{BOX 1 Structure of the Draft United Nations Code of Conduct on Transnational Corporations* \\ PREAMBLE AND OBJECTIVES \\ DEFINITIONS AND SCOPE OF APPLICATION \\ ACTIVITIES OF TRANSNATIONAL CORPORATIONS}

A. General and political

Respect for national sovereignty and observance of domestic laws, regulations and administrative practices

Adherence to economic goals and development objectives, policies and priorities

Review and renegotiation of contracts

Adherence to socio-cultural objectives and values

Respect for human rights and fundamental freedoms

Non-collaboration by transnational corporations with racist minority regimes in southern Africa

96 Communication by Sten Niklasson, (25 February 2014) (on file with the author). In his opinion, a period of about ' $12-15$ months .. of systematic preparation, including increased mental awaereness of what material negotiations might require, would have been sufficient.' ibid.

97 Mousouris, in Hamdani and Ruffing (n 1$)$.

98 Communication by the Chair of the Working Group, Sten Niklasson (9 February 2014) (on file with the author). The idea of a balanced Code was already contained in the report of the Group of Eminent Persons, on the basis of which the Commission and Centre were established. More specifically, the Group noted that the Code should be 'a set of recommendations which could be prepared by the commission, and considered and approved by the Economic and Social Council. They should be addressed to both Governments and multinational corporations.' See 'Report of the Group of Eminent Persons to Study the Impact of Multinational Corporations on Development and on International Relations' (n 9) 55 .

THE JOURNAL OF WORLD INVESTMENT \& TRADE 16 (2015) 11-87 
Non-interference in internal political affairs

Non-interference in intergovernmental relations

Abstention from corrupt practices

B. Economic, financial and social

Ownership and control

Balance of payments and financing

Transfer pricing

Taxation

Competition and restrictive business practices

Transfer of technology

Consumer protection

C. Disclosure of information

TREATMENT OF TRANSNATIONAL CORPORATIONS

A. General treatment of transnational corporations by the countries in which they operate

B. Nationalization and compensation

C. Jurisdiction

INTERGOVERNMENTAL CO-OPERATION

IMPLEMENTATION OF THE CODE OF CONDUCT
A. Action at the national level
B. International institutional machinery
C. Review procedure

Source: Commission on Transnational Corporations, 'Report on the Special Session (7-18 March and 9-21 May 1983)', Official Records of the Economic and Social Council, 1983, Supplement No. 7 (E/1983/17/Rev. 1), Annex II.

* No final decision regarding the use and contents of headings and subheadings had been taken.

Encouragingly, developing countries had obtained much of what they had sought concerning guidelines, as many of the guidelines for TNCs had been agreed upon in a relatively short time, even if not in as strong terms as they had sought: ${ }^{9}$ adherence to economic goals and development objectives, policies and priorities; adherence to socio-cultural objectives and values; respect for human rights and fundamental freedoms; non-collaboration by transnational corporations with racist minority regimes in southern Africa; ownership and

99 The first five provisions were agreed upon by the Working Group during its ninth session, 17-28 March 1980.

THE JOURNAL OF WORLD INVESTMENT \& TRADE 16 (2015) 11-87 
control; taxation; competition and restrictive business practices; consumer protection; and disclosure of information. In the case of other topics, certain aspects were agreed upon (e.g., some issues related to the balance of payments and financing; transfer of technology), or depended on the resolution of provisions elsewhere in the instrument (e.g., renegotiation of contracts). Agreement on the remaining guidelines, including on a reference to permanent sovereignty of states and non-interference by TNCs into the internal political affairs of host countries (see the listing in box 1), seemed to be within reach. ${ }^{100}$

Developing countries were also not, in principle, against treatment provisions: they had agreed to a number of them during the negotiations. But they had problems (reflecting that they were overwhelmingly host countries) with a number of such provisions (discussed below) that could limit their policy space to regulate foreign investors, and the fact that many of these provisions were couched in more precise legal language than the provisions providing guidelines for TNCs.

Developed countries, for their part, were not in principle against guidelines for TNCs (although some of them had reservations from the beginning), and the guidelines part of the instrument was largely agreed upon. This had been made easier by the fact that - as discussed earlier - developed countries had early on agreed amongst themselves, in the framework of the OECD, and partly to have a common bargaining position for the Code negotiations, on the voluntary OECD Guidelines for Multinational Enterprises. The subsequent draft United Nations Code text generally did not go much beyond what had already been agreed in the context of these Guidelines. ${ }^{101}$ Moreover, the constellation of governments was favorable for the Code negotiations: during the second half of the 1970s, social democratic parties were in power in Germany and the United Kingdom (and, beginning in 1981, in France), and

100 Developing countries also used the negotiations to bring up difficult political issues, especially regarding apartheid in South Africa, reflected in regular resolutions adopted by the Commission.

101 In comparison with the original OECD Guidelines, the Code had paragraphs on the review and renegotiation of contracts, the protection of the environment and consumers, respect for human rights, apartheid, non-interference, ownership and control, and transfer pricing. Some of these issues were subsequently added to the Guidelines in the course of the review process of this instrument. Moreover, the United Nations Code was much more detailed on the disclosure of information and balance-of-payments issues. On the other hand, the Guidelines had provisions dealing with competition, employment and industrial relations, and science and technology (although the last two issues were envisaged to be dealt with via references to the ILO Declaration and the technology code under negotiations), however all were not dealt with in the Code.

THE JOURNAL OF WORLD INVESTMENT \& TRADE 16 (2015) 11-87 
the Democrats in the United States. These countries, together with a few others, especially Switzerland and the Netherlands, were not only important home countries (and hence had a special interest in the treatment of their TNCs), but their governments were close to trade unions - and trade unions were keenly aware of the challenges that TNCs presented to them in terms of collective bargaining with firms that could potentially shift production, and hence employment, abroad. ${ }^{102}$ Other Western European governments were supportive as well - some on the basis of the approach 'If you can't beat them, join them.'103 But even before the Carter administration, United States Secretary of State Henry Kissinger had stated publicly in 1975 that his government 'was prepared to make a major effort' to arrive at 'an agreed statement of basic principles, ${ }^{\prime}{ }^{104}$ reflecting the interests of the largest home country in deflecting criticism of TNCs. He later elaborated in a speech to the United Nations General Assembly that:

The United States therefore believes that the time has come for the international community to articulate standards of conduct for both

102 Trade unions generally supported a multilateral approach as they knew, from their own experience, that effective interaction with TNCs would be greatly helped by access to international information as well as by consultation arrangements within individual TNCs (including in the framework of worker world councils), and to have access to an international complaint mechanism: 'It is the trade union view that implementation [of international codes] at the enterprise level is necessary to deal with the normal 99 out of 100 cases, as opposed to the exceptional one in 100 cases which may be discussed at the level of the responsible international organization.' Stephen K Pursey, 'The Trade Union view on the Implementation of Codes of Conduct' in Horn (n 6o) 278. See also Kari Tapiola, 'The Review of the OECD Guidelines: A Trade Union Evaluation' in Horn (n 6o) 291-293. Trade unions had also formulated their own code of conduct for TNCs; see ICFTU, 'Multinational Charter', IFTU Doc D/1976/0403/13.

Communication by Marino Baldi (13 January 2014) (on file with the author). The idea was that, if a code could not be prevented, one should engage constructively in the negotiations and make the best out of them. In the case of some countries (eg Switzerland), this approach was furthered by a desire to protect one's own TNCs (see the observation made earlier about the legitimacy of these enterprises in light of world-wide criticism) and frequent interactions with stakeholders, some of whom supported a code.

Henry Kissinger, 'International Law, World Order, and Human Progress'. Address by Secretary Kissinger made before the American Bar Association at Montreal and Quebec, Canada on 11 August 1975 (Department of State Bulletin, vol 73, No 1889, 8 September 1975), 361. It should be noted, however, that Kissinger also stated that '[a] multilateral treaty establishing binding rules for multinational enterprises does not seem possible in the near future.' ibid.

THE JOURNAL OF WORLD INVESTMENT \& TRADE 16 (2015) 11-87 
enterprises and government... We must reach agreement on balanced principles. These should apply to transnational enterprises in their relations with governments, and to governments in their relations with enterprises and with other governments. They must be fair principles, for failure to reflect the interests of all parties concerned would exacerbate rather than moderate the frictions which have damaged the environment for international investment. ${ }^{105}$

In any event, representatives of important developed countries participated actively in the negotiations. Reflecting their position as the principal home countries, and in spite of some sympathies on the part of some governments for a voluntary code, they were particularly interested in strong investment protection provisions. As mentioned earlier, at a minimum, they wanted to avoid a weakening of the existing standards of customary international law; if anything, they wanted to affirm and strengthen these standards.

Accordingly, the negotiations of the treatment aspect of the instrument during the later time of the Working Group revolved around a number of key investment protections, and negotiations became considerably more difficult. None of the treatment provisions (see box 1) were fully agreed upon, although parts of them were. At the same time, not all open issues involved equally difficult matters. Pride of place among the difficult provisions belonged to the over-arching effort of developed countries to obtain a confirmation of customary international (investment) law, i.e., that there was a body of universally recognized principles and rules of international law reflecting a minimum standard for the treatment of foreign investors and investments. Developing countries rejected such a confirmation, among other things because they had not participated in the creation of this law. In this context, particularly the Latin American countries (adherents of the Calvo Doctrine at that time)

105 Henry Kissinger, 'Global Consensus and Economic Development'. Address by US Secretary of State to the Seventh Special Session of the United Nations General Assembly, delivered on 1 September 1975 by Daniel P Moynihan, US Representative to the United Nations (Department of State Bulletin, vol 73, No 1891, 22 September 1975) 432-433 (Kissinger made similar statements on other occasions). Kissinger continued to lay out a number of parameters for such an instrument, the first two of which were: '_Transnational enterprises are obliged to obey local laws and refrain from unlawful intervention in the domestic affairs of host countries. Their activities should take account of public policy and and national development priorities. They should respect local customs. They should employ qualified local personnel, or qualify local people through training. - Host governments in turn must treat transnational corporations equitably, without discrimination among them, and in accordance with international law...' ibid.

THE JOURNAL OF WORLD INVESTMENT \& TRADE 16 (2015) 11-87 
insisted that foreign investors should not be treated differently from national investors; rather, the treatment of both should be governed by national law (subject to any international agreements freely entered into by individual states), implying, among other things, that foreign investors need not have access to international dispute settlement. For developed countries, on the other hand, access to international arbitration in the case of disputes between foreign investors and host country governments was of key importance.

This controversy played itself out in provisions dealing with specific standards of treatment. The discussions focused on how the fundamental 'national treatment' standard should be qualified and whether fair, equitable and nondiscriminatory treatment should be provided not only in accordance with national law but also international law. Such a broad standard went too far for developing countries, partly because of the reference to international law. Another very controversial standard concerned nationalization, an issue that had just recently been hotly debated in the context of the Charter of Economic Rights and Duties of States adopted in December $1974 .{ }^{106}$ While developing countries insisted on formulations close to those in the Charter, including the sufficiency of 'adequate compensation' and dispute settlement only under domestic law (providing a number of specifications), developed countries insisted, among other things, on 'prompt, adequate and effective' compensation under international law (enumerating elements that needed to be taken into account).

Moreover, there were a few other difficult issues that were of overarching importance. One was the legal nature of the Code (binding vs. voluntary, and reflected in the usage of 'should/shall' brackets in the text of the draft): developing countries sought binding guidelines, but did not want to agree to binding treatment provisions, especially when developed countries sought to make them what developing countries at that time considered onerous. Since it was clear that the basic quid pro quo for an agreement was the trade-off between guidelines for firms and treatment standards for host country governments,

106 See n 10. There, the issue was worded as follows in Article 2(c): 'Each State has the right ... [t]o nationalize, expropriate or transfer ownership of foreign property, in which case appropriate compensation should be paid by the State adopting such measures, taking into account its relevant laws and regulations and all circumstances that the State considers pertinent. In any case where the question of compensation gives rise to a controversy, it shall be settled under the domestic law of the nationalizing State and by its tribunals, unless it is freely and mutually agreed by all States concerned that other peaceful means be sought on the basis of the sovereign equality of States and in accordance with the principle of free choice of means.' Note, however, that the Charter was not adopted by consensus.

THE JOURNAL OF WORLD INVESTMENT \& TRADE 16 (2015) 11-87 
making the treatment standards too demanding would decrease the interest of developing countries in an instrument. Conversely, making the treatment standards too weak and the guidelines too strong (and binding) would decrease the interest of the developed countries in an instrument. The position of the developed countries in this respect was foreshadowed in the nature of the 1976 OECD Declaration, as well as by the fact that the proposal of the Workers' Group in the ILO to formulate a binding convention 'went down in flames'107 during the 1976 World Employment Conference. ${ }^{108}$ Although the question was not resolved until the end of the negotiations, it was tacitly expected that the resulting instrument would be voluntary. ${ }^{109}$ To a certain extent, this issue was

107 Tapiola (n 64). As noted earlier, however, the ILO one year later adopted the Tripartite Declaration; although voluntary, it also contained references to a number of ILO conventions that were binding for those governments that had ratified the conventions in question, and it established a follow-up mechanism.

108 The discussion regarding TNCs in the summary report of the Conference stated that members of the Workers' Group felt that 'it was necessary that a code of conduct should be elaborated at the international level defining the obligations of multinational enterprises. This code should take into account notably the principles and measures presented by the workers' members. It should have a legal and binding form.' It also stated that members of the Group of 77 'recommended that the ILO and member States co-operate with a view to bringing the UN Commission on Transnational Corporations to consider among the points to be in the compulsory Code of Conduct of TNCs those concerning the obligation of these enterprises to hire local labour ...' In contrast, the members of the Employers' Group expressed that a 'voluntary code could be helpful.' The Employers' members felt that an effective Convention would not be helpful unless the guidelines were 'non-mandatory', and that they do not bind multinationals to observance of ILO standards. See International Labour Office, Meeting Basic Needs: Strategies for Eradicating Mass Poverty and Unemployment. Conclusions of the World Employment Conference 1976 (ILO 1977). Interview with Sotirios Mousouris (9 December 2013) and Marino Baldi (2 December 2013). Apart from political considerations, a binding (ie, legally enforceable) instrument would have raised all sorts of complicated issues, including with respect to investigation, the collection and assessment of facts and penalties. While negotiating a voluntary instrument could and should have made reaching an agreement easier, in the case of the United States, however, there was a fear that even a voluntary instrument, as soft law, could potentially be used in that country's courts against firms. For a general discussion of the ways in which soft law principles 'harden' over time and are used a gap-filling measure in United States jurisdicitons, one author used the Sullivan and MacBride principles as an example: 'The Principles have, however, been drawn on as guidelines by state and local governments in the USA for investment, procurement or other purposes, and in that very limited sense they may be considered to have been incorporated into law by reference in certain jurisdictions. They have never, however, been drawn on for these

THE JOURNAL OF WORLD INVESTMENT \& TRADE 16 (2015) 11-87 
sidestepped by seeking to make the United Nations Code 'effective, comprehensive, widely accepted, and universally adopted'110 - which underlined, in turn, the importance of the implementation mechanism.

Implementation of the Code was, indeed, a controversial issue, especially the strength of the implementation mechanism. There was agreement on action at the national level, the role of the Commission as the focal international body within the United Nations system for all matters related to the Code and the role of UNCTC in providing assistance relating to the implementation of the Code. But other provisions remained open. From the perspective of developing countries, a strong international implementation mechanism was desirable for the guidelines aspect of the instrument. From the perspective of developed countries, it was a good thing for the treatment aspect of the instrument - and vice versa: a strong implementation mechanism was undesirable for developing countries as far as treatment was concerned, and it was undesirable for developed countries as far as the guidelines were concerned. In the end, the second set of considerations prevailed, and agreement could not be reached. For the developed countries, even a weak implementation mechanism, patterned on the OECD Guidelines, was problematic, as it could create a 'slippery slope' and, eventually, could lead to the Commission on Transnational Corporations acquiring quasi-judicial powers and becoming a tribunal in which 'their' firms would be put in the dock, even if the instrument itself would be a voluntary one.

Finally, the provisions dealing with definitions and scope of application as well as intergovernmental cooperation were outstanding. As to the former, the key issue was whether the instrument should apply only to private enterprises or also to state-owned enterprises, i.e., whether or not the United Nations Code should be universal; the issue was never formally resolved.111 As to the

purposes in any other non-US jurisdiction, national or international. The Principles, then, are not in themselves soft law, though they may be said to have become soft law in some US jurisdictions through incorporation in governmental decision-making.' Christopher McCrudden, 'Human Rights Codes for Transnational Corporations: What Can the Sullivan and MacBride Principles Tell Us?' (1999) 19:2 OJLS 199.

ECOSOC Res. E/1980/6o, para 6(a), United Nations document E/RES/198o/8o/Add.1 (24 July 1980).

At the 1983 special session of the Commission on Transnational Corporations, the Chair of the Working Group presented a package proposal that also contained language on 'Definitions and scope of application', with a footnote saying ' $[\mathrm{r}]$ egarding the concerns that have been expressed by some delegations on certain points in this package, it was felt that they could be dealt with by reflecting them in the report.' See Commission on Transnational Corporations, 'Report on the Special Session (7-18 March and 9-12 May 1983)' 
intergovernmental cooperation provisions, consensus depended largely upon the decision regarding the legal nature of the resulting instrument.

While the draft text contained many brackets, and the positions on a number of the key outstanding issues appeared insurmountable, the Chair of the

ECOSOC, E/1983/17/Rev 1, 30. However, 'some delegations emphasized that, in their view, it should be made clear that all enterprises, irrespective of their country of origin and form of ownership, should be explicitly covered.' ibid 2. For a review of the discussions concerning the definition, see Dell ( $\mathrm{n}_{1}$ ).

The definition question, under the heading of 'universality', impacted not only the negotiations of the Code but also the relationship between UNCTC and especially the United States in the mid-1980s. The issue was whether a Code, as well as UNCTC's work, would cover all firms that controlled assets abroad, regardless of the nature of their ownership (the position of the developed countries and especially the United States, on the strength of the argument that it is not ownership that matters but behavior and impact) or only non-state-owned enterprises (the position of the socialist countries, on the strength of the argument that state-owned enterprises were not only commercial entities but also served broader societal goals and, in any event, were subject to government control concerning their behavior). Initially, it appears that France and Italy were also somewhat hesitant to include state-owned enterprises, given the importance of these firms in their economies. Communication by Marjan Svetlicic (4 January 2014) (on file with the author).

In 1986, at the time when Ambassador Alan L Keyes represented the United States at the United Nations in New York, the 'universality' issue became one reason for which the United States was seen as no longer broadly supporting the work of UNCTC. To quote Juliana Geran Pilon, from a publication prepared for the Heritage Foundation, a conservative think tank in Washington DC, on this issue: 'The double standard on TNCs [referrring to the possible excemption of state-owned enterprise] is the principal reason why for more than a year the U.S. has distanced itself from the CTC.' Juliana Geran Pilon, 'The Centre on Transnational Corporations: How the UN Injures Poor Nations' (Heritage Foundation 1987) Backgrounder no 6o8, 4. Consequently, Pilon concluded: 'The time now has come for the US to cease participation in the CTC altogether.' ibid 11.

It is somewhat ironic that, 35 years later, the United States, as well as other developed countries, seem to depart from the universality principle of rules for foreign investors by seeking separate rules for state-owned enterprises, eg in the context of the Trans-Pacific Partnership negotiations. This reflects the rise of state-owned enterprises as outward investors from emerging markets, and especially China, although state-owned enterprises headquartered in developed countries control considerably more assets abroad than those headquartered in emerging markets; see Karl P Sauvant and Jonathan Strauss, 'State-Controlled Entities Control Nearly US 2 Trillion in Foreign Assets' (2012) 64 Columbia FDI Perspective <http://ccsi.columbia.edu/files/2014/o1/FDI_64.pdf> accessed 14 September 2014. UNCTC, in its work, dealt with all enterprises; see eg UNCTC, Trends and Issues in Foreign Direct Investment and Related Flows (UNCTC 1985), which devoted one of its chapters to FDI in and from socialist countries.

THE JOURNAL OF WORLD INVESTMENT \& TRADE 16 (2015) 11-87 
Working Group pointed out, when he submitted the draft Code to the Commission in $1982,{ }^{112}$ that ' $[\mathrm{m}]$ ore than half of the bracketed paragraphs contain brackets which could be removed without great effort'113 (e.g., brackets that contained alternatives such as 'refrain from' versus 'not resort to') while the resolution of other brackets depended on matters to be resolved elsewhere.

He further opined that there were only 'five or six hard core difficulties' that needed to be resolved, ${ }^{114}$ and these were the real sticking points in the negotiations. More specifically, the most difficult issues that were outstanding included (not counting the question of implementation and definition), ${ }^{115}$ provisions relating to international law/obligations; national treatment and fair and equitable treatment; nationalization and compensation; settlement of disputes; jurisdiction; and respect for national sovereignty. ${ }^{116}$ The difficulty to reach consensus on these interlinked provisions reflected precisely the different underlying interest situations, and hence objectives, of developed countries as the principal home countries seeking a strong and unambiguous role for international investment law versus the interests of developing countries as the principal host countries seeking to preserve as much as possible of their sovereign right to deal with TNCs according to their own laws and regulations.

Finding the right balance between these objectives could have been a possibility as there were compromise suggestions on the table that appeared to command wide support, including within the group of developed countries. For example, it appears that developing countries and most developed countries could have accepted a general provision requiring countries to fulfill in good faith their 'international obligations' instead of having a reference to 'international law.'117 Overall, all agreed provisions were agreed upon

112 Presentation of the Chair of the Working Group, Sten Niklasson, to the eighth session of the Commission on Transnational Corporations, quoted in E/C.10/1983/S/2. See also 'The United Nations Code of Conduct on TNCs' (1983) 14 The CTC Reporter 9-10. Presentation of the Chair of the Working Group, Sten Niklasson, to the eighth session of the Commission on Transnational Corporations, 9. ibid.

115 While not resolved, there were signs that the socialist countries were prepared to accept a definition that could have covered state-owned enterprises, even if not explicitly so.

Additional issues that were relatively complicated included non-interference in internal political affairs and transfers of payments by TNCs. See also the discussion by Asante, 'The January 1986 Reconvened Special Session' (n 95).

117

See Asante (n 95) 28-30. But some, eg in the United States, saw a real difference between 'international obligations' and 'international law', with the former being obligations that individual governments could decide to accept or not to accept, and the latter referring to 
ad referendum: as customary in international negotiations, nothing is agreed until everything is agreed. With some constructive interpretive ambiguity, ${ }^{118}$ the United Nations Code - and with it the first comprehensive multilateral instrument dealing with investment - appeared within reach.

It was not to be. The negotiations were never successfully concluded - they fizzled out. Negotiations had been particularly intensive during the late $1970 \mathrm{~s}$ and the early 1980 s and were progressing relatively well when the Intergovernmental Working Group on a Code of Conduct met twice annually between 1977 and 1982. When the draft Code was passed on from the Working Group to the Commission in 1982, two-thirds of its 71 provisions (see box 1 - not counting the section on preamble and objectives) were fully agreed. The remaining provisions had brackets, indicating that disagreement existed (while providing alternative formulations) - sometimes signaling strong disagreement, while sometimes final agreement was dependent on how other matters were settled within the text.

With a view toward resolving important outstanding issues, negotiations were even elevated ${ }^{119}$ to special sessions of the Commission on Transnational Corporation, open to the participation of all states, in 1983 (until 1990). ${ }^{120}$ During the 1983 special sessions, progress was made on a number of provisions, resulting in a draft text with fewer brackets, indicating open issues. ${ }^{121}$ But no

legal standards to be observed by all. As regards national treatment, Marino Baldi, the Chair of the Western Group, thought that a compromise seemed to be quite possible (interview with Marino Baldi, 2 December 2013). International investment agreements typically have included broadly-worded key concepts that become only more concrete in the course of the interpretation by arbitration tribunals.

119 Upon a decision of ECOSOC resolution 1982/68 of 27 October 1982.

120 The Special Session of the Commission met 7-18 March, 9-21 May 1983; 9-13 January, 11-29 June 1984; 17-21 June 1985; 20-31 January, 14 April 1986; 6 April 1987; and 24 May 1990. For the draft text of the United Nations Code, as it stood at the end of the negotiations in the Intergovernmental Working Group and the end of the 1983 Special Session of the Commission on Transnational Corporations (reflecting open issues through brackets) see Commission on Transnational Corporations, 'Report on the Special Session (7-18 March and 9-21 May 1983)' (E/1983/17/Rev 1, 1983, Supplement No 7) Annexes II and III. The text is also reproduced in UNCTAD, International Investment Instruments: A Compendium. Volume I: Multilateral Instruments (UNCTAD 1996) 161-180. While negotiations continued, this text reflects the furthest level of consensus reached at the level of the Commission. It should be noted, though, that further progress was made by the Bureau of the June 1985 reconvened Special Session of the Commission. But at the January 1986 Special Session, it was explicitly noted (para 8) that it would 'be misleading to assume that a consensus was reached on any particular formulation. See Commission on 
further progress was made after that date, at least at the level of agreement with a formal status, ${ }^{122}$ despite a number of additional Special Sessions and various other efforts.

Rather, negotiations began to slow down after 1983. The Commission's Expert Advisers made a special effort to help bring about a final compromise, as did the Secretariat, the Chair of the Special Session of the Commission, and the President of the General Assembly of the United Nations. To no avail.

The Expert Advisers to the Commission played an important role. This was a group of eminent personalities, appointed in their personal capacity from business, trade unions, non-governmental organizations, and academia; they hailed from developed, developing and socialist countries. They met on their own during the June 1985 reconvened Special Session of the Commission to seek compromise texts for the principal outstanding issues. They succeeded in doing so on the basis of the assumption that the Code would be non-mandatory, ${ }^{123}$ indicating that it was feasible among different stakeholders to arrive at consensus. These formulations were subsequently submitted to the Special Session of the Commission. The submission of the Expert Advisers helped interested delegates, but, in the end, did not unblock the negotiations. Individual 'Friends of the Centre' also sought to help in other ways, e.g., by arranging for Hearings in the United States Congress. ${ }^{124}$

Transnational Corporations, 'Report on the Reconvened Special Session (20-31 January 1986)' (E/1986/50, 14 February 1986) para 8.

The January 1986 Special Session of the Commission had before it various texts, including suggestions for the solution of the outstanding issues proposed by the Bureau of the June 1985 reconvened Special Session. Such texts dealt with: fair and equitable treatment; a general provision on the interrelatedness of the Code's provisions; observance of domestic laws; and jurisdiction. However, none of these suggestions were given formal status in the Special Session's report. See Commission on Transnational Corporations, 'Report on the Reconvened Special Session (20-31 January 1986)' (E/1986/50, 14 February 1986). See also The CTC Reporter ( $\mathrm{n}$ 95) 18. The joint statement is reproduced in (1985) 20 The CTC Reporter 18-19. The names of the Expert Advisers can be found there as well.

124 Esther Peterson, the representative of the International Organization of Consumers, arranged for Hearings on the status of the Code negotiations held by the Subcommittee on Human Rights and International Organizations of the Committee on Foreign Affairs, United States House of Representatives, on 7 May 1987; Peter Hansen (who was UNCTC's last Executive Director, serving from 1985-1992, and the highest-ranking UNCTC staff responsible for the Code negotiations) was in the audience and was called upon to clarify certain issues that were discussed; see 'Congressional Support for the Code' (1987) 24 The CTC Reporter 31-36, including excerpts from the testimonies. The same Subcommittee held Hearings again on 15 November 1989, in which a number of eminent personalities

THE JOURNAL OF WORLD INVESTMENT \& TRADE 16 (2015) 11-87 
Similarly, various efforts by UNCTC - which throughout the negotiations had prepared numerous supporting documents, had actively supported the Chair of the negotiations, and had provided technical advice especially to developing country negotiators - did not lead to a breakthrough. For example, an informal roundtable in Montreux organized by UNCTC in October 1986 brought together key negotiators and others to assist the Commission to reach agreement on the Code. ${ }^{125}$ Another such meeting, also organized by UNCTC, in The Hague (Netherlands) in September 1989, involved prominent international lawyers as well as key negotiators. ${ }^{126}$ Both meetings sought to move the negotiations forward on a number of important outstanding issues, but neither succeeded. ${ }^{127}$ Meetings were also organized by the United Nations' regional economic commissions for Africa, Asia and the Pacific, Western Asia, and Latin America and the Caribbean during the last quarter in 1985, in preparation for the Commission's Special Session in January $1985 .{ }^{128}$

In a last-ditch attempt, the Chair of the Special Session of the Commission, Miguel Marin-Bosch (Mexico), sought to arrive at a final compromise text:

In May 1990, towards the end of what turned out to be the last meeting of the reconvened special session of the Commission, I requested the

testified; see 'Congressional Hearings on the Code' (1990) 29 The CTC Reporter 1-14 (including excerpts from the experts' statements). Peterson also arranged for such Hearings in the United States Congress Senate Foreign Affairs Committee on 11 October 1990; see 2:3 Transnationals 1-2 (Quarterly Newsletter of the United Nations Centre on Transnational Corporations). Finally, Peterson arranged for the author of this article to be an Expert Witness in the Hearings on 'Foreign direct investment' (on the United Nations Code) of the Joint Economic Committee of the Congress of the United States, Washington DC, 13 May 1992 (special permission by the United Nations was required to accept this invitation to testify as Expert Witness).

125 For the 'General Reflections on the United Nations Code of Conduct on Transnational Corporations' adopted by the Roundtable, as well as the list of participants, see (1986) 22 The CTC Reporter 9-10. The Roundtable did not put forward any joint concrete proposals. As Victoria Aranda observed: 'As on previous occasions in the last three years, the political will to find a solution to the outstanding issues in the negotiations on the Code was absent.' See Victoria Aranda, 'The Thirteenth Session of the Commission on Transnational Corporations: Highlights' (1987) 24 The CTC Reporter, ibid 3.

126 For the outcome of that symposium (as well as the list of participants) see (1990) Reporter (n 124) 26-27.

127 Convened on the initiative of UNCTC's Executive Director at that time, Peter Hansen, these meetings also illustrate the activist approach that the Centre took to help move the negotiations along.

128 See (1986) Reporter (n 95) 20.

THE JOURNAL OF WORLD INVESTMENT \& TRADE 16 (2015) 11-87 
members of the Western European and Others Group to share with me the wording of the outstanding issues that would be acceptable to them. I then incorporated the language suggested, especially by the delegates of the U.K. and the U.S., into my own draft code and circulated the revised text. ${ }^{129}$

But even that text ${ }^{130}$ was not acceptable to key developed countries: 'the draft code of conduct, even as amended, simply "did not smell right"'131 For the Governments of the United States and the United Kingdom, in particular - but also for those of some other developed countries that conveniently left the lead to the United States - the United Nations Code had simply become anachronistic and unacceptable, a proxy for the discussions relating to a New International Economic Order which they wanted to be over with for good. ${ }^{132}$ To quote from a demarche that the United States Government had sent in March 1991 to the countries embassies abroad, asking embassy staff to lobby for the termination of the Code negotiations:

We believe that the Code is a relic of another era, when foreign direct investment was looked upon with considerable concern. The Code does not reflect the current investment policies of many developing countries. ... In light of the above, Washington agencies have decided to seek the support of host government officials responsible for foreign investment and quietly build a consensus against further negotiations. ... We stress that the Demarche should be given to officials responsible for investment not/not those responsible for UN affairs. ${ }^{133}$

129 Miguel Marin-Bosch, 'An Odorless Code' in Hamdani and Ruffing (n 1) (Marin-Bosch was Deputy Permanent Representative and then Permanent Representative of Mexico to the United Nations in New York during the Code negotiations and, in 1984, became the Chair of the Special Session of the Commission on Transnational Corporations).

Letter dated 31 May 1990 from the Chairman of the reconvened special session of the Commission on Transnational Corporations to the President of the Economic and Social Council transmitting a proposed text of the Draft Code of Conduct on Transnational Corporations (E/1990/94) (Report of the Economic and Social Council for the Year 1990, United Nations New York 1991 (A/45/3/Rev1) 48-49).

As the Heritage Foundation put it: 'A much more important objection is that the Code is designed to force Western companies to operate according to the New International Economic Order - or NIEO - the UN's prescription for mandatory resource transfers from the West to the developing world.' Pilon (n 111) 2.

Quoted in John Braithwaite and Peter Drahos, Global Business Regulation (CUP 2000) 193. 
In any event, it is not at all clear whether the Chair's text would have been acceptable to developing countries (especially in Latin America), considering that the key outstanding issues had all been resolved along the lines of solutions proposed by developed countries. As Marin-Bosch put it: 'The developing countries did not voice an opinion on my "developed country" text. The dialogue was between the Chair and the US and UK delegates. When those two delegations voiced their opposition and the Eastern Group said nothing, there was really no need to find out what the G-77 thought.'134 For all practical purposes, this signaled the end of the Code negotiations.

Not surprisingly, therefore, a subsequent special consultation effort by the President of the General Assembly of the United Nations ${ }^{135}$ during 1991 did not lead to further progress. An additional round of informal consultations took place during 21-23 July 1992, conducted by Farooq Sobhan (Bangladesh), the Chair of the eighteenth session of the Commission on Transnational Corporations, on behalf of the President of the General Assembly. The Chair concluded: 'It became clear in the course of the consultations that neither the developed nor the developing countries were any longer interested in continuing the negotiations. There was therefore no way we could obtain an intergovernmental Code. ${ }^{136}$ Accordingly, the President of the General Assembly reported in September 1992 that: 'It was the view of delegations that no consensus was possible on the draft code at present. Delegations felt that the changed international economic environment and the importance attached to encouraging foreign investment required that a fresh approach should be examined...' ${ }^{137}$ In light of this, the Commission on Transnational Corporations, during its nineteenth session in April 1993, requested ECOSOC to adopt a resolution to take note 'of the results of the consultations on the draft code of conduct on transnational corporations held by the President of the General Assembly from 21 to 23 July 1992.' ${ }^{138}$ With ECOSOC endorsing the draft, ${ }^{139}$ this marked the formal end of the negotiations of a United Nations Code of Conduct on Transnational Corporations. Negotiators never managed to

\footnotetext{
134 Communication by Miguel Marin-Bosch (26 February 2014) (on file with the author).

135 As requested by the General Assembly in its resolution 45/186 of 21 December 1991. The report of the President is contained in document A/46/558 and Corr of 16 October 1991.

136 Interview with Farooq Sobhan (4 March 2014).

137 See 'Report of the Economic and Social Council: Note by the Secretary-General' (A/47/446, 15 September 1992).

138 Para 14 of the draft resolution 'Strengthening the Role of the Commission on Transnational Corporations' contained in the 'Report of the Commission on Transnational Corporations on its Nineteenth Seession (5-15 April 1993)' (E/1993/30, 9 June 1993).

139 ECOSOC resolution 1993/49 (29 July 1993) para 14.
} 
reconcile, or did not want to reconcile, the different underlying interest situations of developed and developing countries.

\section{$5 \quad$ Why the Failure?}

Perhaps ambitions were too high, perhaps the agenda of subjects to be tackled was beyond what was possible, perhaps one ought to have dealt with the most difficult issues at the beginning (when pressure was the highest), perhaps the venue was not the right one, ${ }^{140}$ perhaps it is too much to deal with such a complex topic in one instrument, or perhaps key countries simply did not consider any possible trade-off as satisfactory given the different underlying interest situations of developed and developing countries and the objectives flowing from them. It is certainly a formidable challenge to negotiate a comprehensive multilateral instrument on such a complex and difficult subject as international investment, especially if it seeks to cover both, protection and liberalization, ${ }^{141}$ let alone guidelines for firms. This challenge is further accentuated by the fact that foreign investment is very intrusive as it involves the entire range of issues related to the production process within national economies (and FDI has the additional baggage of being 'foreign'). The effort could perhaps only have succeeded if both country groups had a strong vested interest in the success of the negotiations, and even then only as a voluntary instrument. ${ }^{142}$

Most importantly, however, as the negotiations slowed down and became drawn out, the interest in a United Nations Code cooled because regulatory, economic and political macro-level circumstances were unfolding that changed the interests of developed and developing countries in a multilateral

140 Negotiations under the umbrella of the United Nations General Assembly can easily become more politicized than in other fora. The 1970 (but less so during the 1980s) were particularly politically charged on account of the NIEO discussions.

Marino Baldi, eg argued that aiming for a comprehensive investment instrument makes it very difficult to reach agreement, especially if it seeks to cover both protection and liberalization; see 'Are Trade-law Inspired Investment Rules Desirable?' (2013) 105 Columbia FDI Perspectives <http::/ccsi.columbia.edu/files/2014/01/FDI_105.pdf> accessed 14 September 2014 .

Recall that even in the context of the OECD it had not been possible to negotiate a binding instrument in 1976, at the height of the criticism of TNCs. Even the earlier OECD effort to adopt a 'Convention on the Protection of Foreign Property' did not succeed (the draft is reproduced in (1968) 7 ILM 117-143 Similarly, the later effort to negotiate a binding Multilateral Agreement on Investment in the OECD came to naught.

THE JOURNAL OF WORLD INVESTMENT \& TRADE 16 (2015) 11-87 
instrument that would establish norms for international investors and the treatment of those investors.

Instead, international investment agreements (IIAs ${ }^{143}$ - particularly BITs, to which one has to add other international agreements that contain substantial investment provisions) focused, and continue to focus, on what was, at that time, the single most important objective of the developed countries: to protect the investment of their investors abroad by establishing mandatory standards of treatment of foreign investors by the governments of host countries, subject to binding dispute settlement through international arbitration. By the end of the 1980s, 371 BITs had been negotiated ${ }^{144}$ and by the end of the $1990 \mathrm{~s} 1,862 .{ }^{145}$ By the end of 2013, that figure had reached 2,902 BITs and 334 other IIAs. ${ }^{146}$ In their totality, IIAs constitute a powerful protective mechanism for foreign investors, as witnessed by the rising number of treaty-based international investment disputes, which, cumulatively, had reached at least 568 by the end of $2013 .{ }^{147}$ Moreover, the scope of these treaties, at least in the case of a number of important developed home countries, gradually expanded beyond protection to include various liberalizing provisions, particularly national treatment at the pre-establishment phase of an

143 This concept was used by UNCTC as far back as 1990; see UNCTC (n 92). UNCTAD's World Investment Report 1996: Investment, Trade and International Policy Arrangements (UNCTAD 1996) 181 (used 'international investment agreements').

144 Only BITs still in effect in 2013. Courtesy UNCTAD Secretariat.

145 ibid.

146 ibid; see also UNCTAD, World Investment Report 2014: Investing in the SDGs. An Action Plan (UNCTAD 2014) 114.

147 UNCTAD (n 146) 124. This number might appear low, considering that there are more than 100,000 MNEs and more than one million foreign affiliates, each of which, depending on the availability of an IIA and its provisions, could potentially initiate dispute proceedings. On the other hand, the number of disputes on which panel reports were issued during the existence of the GATT from 1948 to the end of 1994 (when the WTO came into existence) amounted to only 91. See Karl P Sauvant, 'Driving and Countervailing Forces: A Rebalancing of National FDI Policies' in Karl P Sauvant (ed), Yearbook on International Investment Law \& Policy 2008-2009 (OUP 2009) 215, 259. It is important to note that there is of course an important difference between the WTO dispute-settlement regime and the IIA dispute-settlement regime: in the case of the former only states can initiate disputes, while in the case of the latter only investors can do that. Additionally, the large number of TNCs and their foreign affiliates, combined with the large number of IIAs and a broad definition of 'investment', also indicates that there is a considerable potential for future disputes, underlining the importance of the dispute-settlement mechanism and explaining to a certain extent the concern of governments and others in this area.

THE JOURNAL OF WORLD INVESTMENT \& TRADE 16 (2015) 11-87 
investment. ${ }^{148}$ The rise of BITs furthered the demise of the United Nations Code as BITs provided developed countries with the strongest possible mandatory protection for their investors without any guidelines for firms, ${ }^{149}$ as well as a dispute-settlement mechanism that would enforce this protection.

Moreover, while the number of IIAs rose, the ideological climate changed in developed countries. With the election of Prime Minster Thatcher in the United Kingdom in 1979 and President Reagan in the United States in 1980, free market principles began to dominate. Guidelines for firms, let alone mandatory ones, were no longer in the cards - in fact, they became anathema. ${ }^{150}$ And the disintegration of the socialist camp, indeed of the Soviet Union itself, deprived developing countries of allies ${ }^{151}$ (although the end of the Cold War

148 However, efforts to enshrine investment protections inter-regionally did not succeed: as already noted, the idea to adopt an OECD 'Convention on the Protection of Foreign Property' and negotiate a Multilateral Agreement on Investment (MAI) that would be open to other countries came to naught. The same applies to efforts to negotiate an investment agreement in the framework of the WTO. For a discussion of why the MAI negotiations failed, see Edward M Graham, Fighting the Wrong Enemy:Antiglobal Activists and Multinational Enterprises (Peterson Institute 2000); Charan Devereaux, Robert Z Lawrence and Michael Watkins, Case Studies in US Trade Negotiation, Making the Rules (Institute for International Economics 2006) vol 1; UNCTAD, Lessons from the MAI. UNCTAD Series on Issues in International Investment Agreements (United Nations 1999). A part of the documentation related to the MAI negotiations <http://www.oecd.org/daf/ mai/>accessed 14 September 2014.

However, the later MAI drafts included provisions on the non-lowering of environmental and social standards and references to the OECD Guidelines, as do a number of post-20oo BITs.

This change in the ideological approach also had implications for the OECD Guidelines for Multinational Enterprises: beginning in the mid-1980s and especially during the 1990s, fewer cases/issues were brought to the OECD's Committee on International Investment and Multinational Enterprises (CIME). The Guidelines appeared to be moribund, and the separate Working Group on the Guidelines for Multinational Enterprises dealing with cases was abolished by combining it with another. Only with the 2000 review of the Guidelines did this instrument obtain new vitality. A separate Working Party dedicated to dealing with the Guidelines was re-established only in 2013, the Working Party on Responsible Business Conduct.

151 The support of the socialist countries had, however, been a double-edged sword. On the one hand, these countries provided rhetorical support for the developing countries, claiming at the same time that they themselves were neither home nor host countries to TNCs, and thus in reality not affected by the whole exercise. On the other hand, to quote Guttorm Vik, 'the unnatural and unholy alliance often prevailing between the $\mathrm{G}_{77}$ [the developing countries] and Group D [the socialist countries] during the code negotiations annoyed the hell out of the developed countries and reinforced the resolve of

THE JOURNAL OF WORLD INVESTMENT \& TRADE 16 (2015) 11-87 
meant that the East-West aspect of the subject, including the question of the definition of TNCs, no longer played a role in the United Nations Code discussions and negotiations). ${ }^{152}$

The interest situation of the developing countries, too, changed beginning in the 1980 s. While the oil shock had initially boosted the bargaining power of developing countries, there was not, in the end, sufficient solidarity among them to make producer cartels work across various natural resources. Importantly, the debt crisis, which had started in Mexico in 1982 (and engulfed other developing countries as well), put non-debt-creating finance at a premium and more stable finance (like FDI) to boot. The 'United Nations Development Decades' had not brought the desired improvements. ${ }^{153}$ This went hand-in-hand with the recognition that FDI brings a bundle of tangible and intangible assets that can make an important contribution to a country's development. The change in the development model from import substitution to export orientation made attracting FDI especially desirable as it helps national economies to link to international markets in a globalizing world economy characterized by integrated international production, i.e., global value chains. ${ }^{154}$ A number of the newly industrializing countries in East Asia showed the usefulness of attracting FDI and non-equity forms of foreign participation. Such investment, therefore, became increasingly sought not only by

the most skeptical opponents to the whole exercise, thus preventing rather than promoting a positive outcome.' Communication by Guttorm Vik (12 April 2014) (on file with the author).

152 The socialist countries were often represented by high-level representatives in the meetings of the Commission. Especially during the late 1980s, this was not only to influence the Commission's discusions, but also to learn more about TNCs and the potential benefits they could bring to host countries. At that time, a number of socialist countries began to allow joint ventures with TNCs in their territories. Interview with Stephen Pursey and Kari Tapiola (8 January 2014).

153 See 1960-1970 - United Nations Development Decade; 1971-1980 - Second United Nations Development Decade; 1981-1990 - Third United Nations Development Decade; and 19912000 - Fourth United Nations Development Decade <http://www.un.org/en/events/ observances/decades.shtml $>$ accessed 14 September 2014.

154 As developing countries turned toward export-oriented development strategies, the role of TNCs in providing access to international markets became a particularly sought-after asset. See UNCTAD, World Investment Report 2002: Transnational Corporations and Export Competitiveness (United Nations 2002) and UNCTAD, World Investment Report 2013: Global Value Chains: Investment and Trade for Development (United Nations 2013). The phenomenon of global value chains was foreshadowed, under the heading 'integrated international production systems' in UNCTAD, World Investment Report 1993: Transnational Corporations and Integrated International Production (UNCTAD 1993).

THE JOURNAL OF WORLD INVESTMENT \& TRADE 16 (2015) 11-87 
indebted developing countries, but also other developing countries and economies in transition that did not want to be excluded from the globalizing world economy. ${ }^{155}$ This was further encouraged by the emerging 'Washington consensus', a plank of which noted that 'a restrictive attitude limiting the entry of foreign direct investment (FDI) is regarded as foolish.' ${ }^{156}$ At the same time, the collapse of the socialist camp during 1989-1992 deprived developing countries of an alternative development model centered on central planning. ${ }^{157}$ Increasingly, developing countries paid more attention to the importance of the private sector and entrepreneurship ${ }^{158}$ and the positive role of FDI. The demystification of TNCs and of their impact, as well as the rising capacity of developing countries to deal with foreign investors (through national regulations, the negotiation of contracts, etc.), facilitated the rapprochement between host developing countries and TNCs - and UNCTC's numerous studies and advisory projects contributed their share to this process. From being a 'bad thing', FDI was more and more seen as a 'good thing' for development; from being part of the problem, it became part of the solution, in fact almost a panacea ${ }^{159}$ - partly as a result of economic need and

155 Changes took also place among developed countries, changes that strengthened economic cooperation among developed countries, but typically did not include developing ones. For example, the members of the European Union launched their Single Market Programme in 1993; Canada and the United States concluded a free trade agreement in 1988; and the NAFTA negotiations started in 1986. Moreover, with the disintegration of the socialist camp, a number of central European countries joined the European Union. John Williamson, What Washington Means by Policy Reform in Latin American Adjustment: How Much Has Happened? (Institute for International Economics 1990) 15.

A point particularly emphasized by José E Alvarez; see his 'The Once and Future Foreign Investment Regime' ( $n$ 45). It should be noted that a number of the socialist countries had already begun to open their economies to FDI, at least in the form of joint ventures, in order to obtain capital and technology.

As reflected, eg in the adoption of United Nations General Assembly resolutions on entrepreneurship. See eg A/RES/41/182 (8 December 1986) on 'Indigenous Entrepreneurs in Economic Development' (adopted without a vote); A/RES/45/188 (21 December 1990) on 'Entrepreneurship' (adopted by vote 138 yes, 1 no (Cuba), o abstentions) (its also contained the following preambular paragraph: 'Welcoming the contribution which the United Nations system makes in helping Member States promote entrepreneurship, including foreign direct investment, and encouraging the active participation of private enterprise, where appropriate', and it decided to include a sub-item entitled 'Entrepreneurship' in the provisional agenda of the 46th session of the General Assembly); and A/RES/46/166 (19 December 1991) on 'Entrepreneurship' (adopted without a vote).

Even though FDI can bring various tangible and intangible assets and serve as a catalyst for domestic development, FDI flows represented only an average of $8 \%$ world gross 
the pressure of reality, and partly as a result of a learning process. All this was facilitated by TNCs, which had of course become aware of the developments in the OECD and the United Nations, and began to accept the concept of 'corporate social responsibility'. A code of conduct for TNCs did not fit into that landscape. ${ }^{160}$

The zeitgeist had changed. Toward the middle of the 1980s, the criticism of TNCs and their foreign investments had died down, and the overlapping self interests between developed and developing countries in a comprehensive instrument had waned. Pressure had ceased. The political will to take action had dissipated. If there had been a window of opportunity for a comprehensive multilateral instrument dealing with TNCs and FDI, it was open at the end of the 1970s and the first two years of the 1980s. At that time, such an instrument was in tune with the zeitgeist. It might have been an instrument that would have combined, in a balanced manner, guidelines for the conduct of TNCs with standards of treatment of foreign investors by host country governments, a voluntary instrument, but one that might have had a modest implementation mechanisms (which, perhaps, could have been strengthened over time). As the 1980 s progressed, the window of opportunity if there had indeed been one - closed for a comprehensive United Nations Code (and other TNC-related international instruments whose negotiations had not been concluded successfully before the mid-1980s), serving as a broad basis for a broad-based architecture of the international investment law and policy regime.

Instead, red carpet came to replace red tape, rolled out by an exploding number of investment promotion agencies at all levels. ${ }^{161}$ Liberalization

domestic capital formation in 2013 ( $7 \%$ for developed countries, $9 \%$ for developing countries, $16 \%$ for transition economies, although this share varies greatly by country); see UNCTAD (n 146) annex tables. In other words, the development effort needs to focus primarily on indigenous enterprises. to deal with international investment in the WTO, including because they feared crossretaliation in the case of the non-observance of such an agreement.

161 It was estimated that, by the end of the first decade of the twenty-first century, some 8,000 agencies at the national and sub-national levels sought to attract FDI; see Millennium Cities Initiative, Handbook for Promoting Foreign Direct Investment in Medium-Size, LowBudget Cities in Emerging Markets (Columbia University 2009). The World Association of Investment Promotion Agencies (WAIPA) was established in 1995 by UNCTAD's Investment Division, the successor of UNCTC; WAIPA has become the world's paramount association of investment promotion agencies. See <http://www2.waipa.org/cms/Waipa> accessed 14 September 2014.

THE JOURNAL OF WORLD INVESTMENT \& TRADE 16 (2015) 11-87 
and protection came to replace the 'taming' and control of TNCs: during the heyday of liberalization in the 1990s, some $95 \%$ of all $(1,641)^{162}$ national FDI policy changes were in the direction of making the investment climate more welcoming for foreign investors, and about 1,500 BITs were concluded. Furthermore, bilateral and regional international investment negotiations moved from protection to liberalization, to facilitate the entry and operations of TNCs in host countries.

As Peter Hansen, UNCTC's last Executive Director, put it: 'The effort to negotiate a comprehensive Code of Conduct in the United Nations was ahead of its time when it was conceived and negotiated. It was never completed because macro-economic and political circumstances changed. But, hopefully, the effort opened the eyes of policy-makers and others about what needs to be done in the area of international investment.'163 Echoed Sten Niklasson: 'It was a process of mutual learning among delegations and it pointed the global search-light towards certain questionable and murky activities of TNCs. It is likely that this international attention triggered self-regulating initiatives in a number of TNCs, although the causal connection will remain unclear. ${ }^{164}$ And similarly Clarke Ellis, the head of the United States delegation for the Code negotiations in 1984-1987: the failure of the negotiations 'does not mean that the exercise was worthless. Through discussion, the developing and socialist countries came to learn of the benefits of foreign investment and the need to treat foreign investors fairly. The developed countries learned about the sensitivities of the developing countries and the need for their companies to be good corporate citizens.' ${ }^{\text {165 }}$

\section{$6 \quad$ Where Do We Stand?}

By the end of the 1990s, the position of developed countries on international norms for international investment had prevailed across the board.

\footnotetext{
162 UNCTAD, World Investment Report 2003: FDI Policies for Development. National and International Perspectives (United Nations 2003) xvii.

163 Interview with Peter Hansen (20 January 2014).

164 Communication by Sten Niklasson (9 February 2014) (on file with the author).

165 Communication by Clarke Ellis (who was the de facto head of the United States delegation to ECOSOC during Fall 1974, when that body established the Commission and UNCTC; from 1984-1987, he was Director of the Office of Investment Affairs in the United States Department of State and head of the United States delegation for the Code negotiations) (dated 28 January 2014) (on file with the author).
} 
The question of comprehensive multilateral ${ }^{166}$ guidelines for TNCs was off the table, as was the question of an international implementation mechanism. On the other hand, international investment law had not only been confirmed, but was more and more supplemented and elaborated through a web of bilateral and regional investment agreements, rather than a multilateral instrument, ${ }^{167}$ and the decisions of a rising number of arbitration tribunals adjudicating investor-state disputes. Fair and equitable treatment and national treatment were widely accepted, as was the standard of 'prompt, adequate and effective compensation' (and criteria related to it) in the case of nationalizations, with fair and equitable treatment as an absolute standard becoming an important ground for firms initiating investor-state disputes. ${ }^{168}$ The protection of investors through proper treatment under international investment law was assured, supported by a functioning investor-state dispute-settlement mechanism (i.e., the Calvo doctrine was abandoned). ${ }^{169}$ Discussions and negotiations moved on to further liberalization.

The change had been dramatic. By the beginning of the $21^{\text {st }}$ century, a strong international investment regime had emerged from the 'ephemeral structure' that Salacuse and Sullivan had noted existed in the mid-1970s. ${ }^{170}$ To quote Thomas W. Wälde:

166 As discussed elsewhere, though, the OECD Guidelines were strengthened in terms of their scope, content and implementation, beginning with the review in 2000, revitalizing in this manner this instrument. Although the General Agreement on Trade in Services (GATS) and the Agreement on Trade-related Investment Measures (TRIMs), negotiated as part of the Uruguay Round, are relevant in this context. See Rudolf Adlung, 'Multilateral Investment Disciplines: Don't Forget the GATS!' (2014) 117 Columbia FDI Perspectives.

168 See eg the discussion in UNCTAD, 'Recent Developments in Investor-State Dispute Settlement (ISDS)' IIA Issues Note, No 1 (2013). Latin American countries began abandoning the Calvo Doctrine and accepting investorstate dispute settlement in their BITs during the late 1980 s and early 1990s. Bolivia accepted an investor-state dispute-settlement provision 1987 in its BIT with Germany (Treaty concerning the promotion and mutual protection of investments (with protocol) between Federal Republic of Germany and Bolivia signed at La Paz on 23 March 1987). Other countries concluded similar BITs as follows: Uruguay - 1987; Argentina and Venezuela - 1990; Chile and Peru - 1991. See Kenneth J Vandevelde, 'A Brief History of International Investment Agreements' (2005) 12 Intl L \& Pol'y 178-179. The first South American countries to sign the ICSID Convention did so in 1991: Argentina, Chile and Peru; see <http://icsid.worldbank.org/ICSID/FrontServlet?requestType=ICSIDDocRH\&a ctionVal=ShowDocument\&language $=$ English $>$ accessed 14 September 2014 .

$170 \quad$ Salacuse and Sullivan (n 47) 68. 
Investment treaties...have built, indubitably, one of the most effective and truly legal regimes within the fragmented and mostly quite rudimentary institutional frameworks for the global economy. Comparable in terms of legal character and effectiveness to the WTO regime, the international investment regime is arguably more advanced, as it fully incorporates the most important and directly affected non-state actors. In a longer-term perspective, claimants (and their lawyers), who are essentially driven by private interests, help ensure greater compliance and effectiveness for the treaties and their underlying objectives than can or is achieved by exclusively inter-state implementation procedures. It also goes beyond the prospective-remedy-only sanction available under the WTO. ${ }^{171}$

He added: 'Investment arbitration is arguably the most astounding success in international law over the past decades...' ${ }^{\text {'72 }}$ Wälde's observations may be correct, at least as seen from the perspective of international investors. But it is less clear whether this is also true from the perspective of other stakeholders and the international investment regime as a whole.

Is this 'the end of history' for the international investment law and policy regime? ${ }^{173}$ It is a regime that covers the most important type of international economic transactions: the value of the sales of the foreign affiliates of TNCs is higher than the value of world exports. ${ }^{174}$ The number of TNCs headquartered in the developed countries had risen from at least 7,000 in the late 1960s, to at least 24,000 as of 1990 , to over 70,000 at the end of $2010,{ }^{175}$ As to the last number, at least 30,000 TNCs headquartered in emerging markets need to be added. These over 100,000 TNCs controlled over one million foreign affiliates at the end of 2010. Moreover, FDI is (as mentioned earlier) more intrusive than trade, as TNCs, by virtue of establishing foreign affiliates, become directly involved in the

171 Thomas W Wälde, 'Improving the Mechanisms for Treaty Negotiation and Investment Disputes: Competition and Choice as the Path to Quality and Legitimacy' in Karl P Sauvant (ed), Yearbook on International Investment Law \& Policy 20o8-20og (OUP 2009) 505, 514.

172 ibid 543 .

173 As Joachim Karl argued in 'The "Spaghetti Bowl” of IIAs: The End of History?' (2014) 115 Columbia FDI Perspectives <http://ccsi.columbia.edu/files/2013/10/No-115-Karl-FINAL .pdf> accessed 14 September 2014 borrowing part of the title of F Fukuyama's volume The End of History and the Last Man (Free Press 1992).

174 In 2013, total sales of foreign affiliates amounted to an estimated USD 35 trillion, while world exports were USD 23 trillion; see UNCTAD (n 146) 24.

175 Fredriksson (n 1) 8; UNCTAD, World Investment Report 2011: Non-equity Modes of International Production and Development (UNCTAD 2011) web annex table. 
production process and the social fabric of their host countries, increasing (as compared to trade) in this manner not only the potential to contribute to the development of their host countries, but also to the potential for conflict. At the same time, there is no multilateral investment instrument that would provide an enforceable over-arching framework applicable to the multi-jurisdictional activities of foreign investors, be it to provide stability and predictability for their operations or avoid overlapping/underlapping regulatory requirements. Rather, the current international investment regime has a light and fragmented institutional structure, is shaped by a multiplicity of (mostly bilateral) legal sources and has broad subject-matter coverage. Its single most important objective is the protection of international investment; ${ }^{176}$ hence standards for the treatment of investors by host countries are at the core of the regime, with arbitration as the chosen, and increasingly criticized, mechanism to settle investment disputes. ${ }^{177}$

It is the last of these characteristics of the international investment regime the singular and deliberate focus on protection - that distinguishes the current regime from that sought in the negotiations of a United Nations Code. That Code sought to establish a balance between the rights and responsibilities of foreign investors on the one hand, and those of host country governments on the other. As discussed, the subsequent developments led to an international regime that enshrines the rights of foreign investors vis-à-vis the governments of host countries and the mandatory responsibilities of host country governments concerning the treatment of foreign investors, leaving the rights of host country governments (vis-à-vis foreign investors and their foreign affiliates) and the responsibilities of foreign investors and their foreign affiliates (vis-àvis host countries) aside.

The first of these imbalances - between the rights of host countries and those of foreign investors and their foreign affiliates - has been the subject of policy developments since the heydays of investment protection and liberalization in the 1990s. In particular, it has become clear that some key international protections, such as fair and equitable treatment, measures tantamount to expropriation, need to be defined more precisely to avoid being interpreted

176 It should be noted that protection is expected to lead to higher FDI flows. There is a lively discussion about the extent to which IIAs (and especially BITs) lead to higher FDI flows. For a collection of studies on this topic and an evaluation of the evidence see Karl $\mathrm{P}$ Sauvant and Lisa E Sachs (eds), The Effect of Treaties on Foreign Direct Investment: Bilateral Investment Treaties, Double Taxation Treaties, and Investment Flows (OUP 2009).

177 For a brief review of the nature of the international investment regime see Karl P Sauvant and Federico Ortino, Improving the International Investment Law and Policy Regime: Options for the Future (Ministry of Foreign Affairs of Finland 2013).

THE JOURNAL OF WORLD INVESTMENT \& TRADE 16 (2015) 11-87 
too broadly. This process was led by the United States and Canada, which had become the respondents in three NAFTA chapter 11 arbitration cases each by 2000, brought by foreign investors against them. ${ }^{178}$ The United States, traditionally a strong proponent of investment protection and liberalization, began to circumscribe key investor protections, as reflected in its 2004 BIT Model ${ }^{179}$ and the treaties based on it, to allow for more national policy space to be able to pursue legitimate public policy objectives without running the risk of becoming respondents in arbitral cases. ${ }^{180}$ Moreover, when essential security interests are affected, the United States, and the parties to its agreements containing a self-judging essential security clause, can disregard the protections enshrined in newer IIAs. Where this occurs, and a claim is being brought against an action taken by the Government of the United States (as well as its treaty partners), it is protected, at least to a large extent, by a clarification that, if the essential security clause is evoked, 'the tribunal or panel hearing the matter shall find that the exception applies.' ${ }^{\text {'181 }}$

It can be expected that other countries will adopt a similar approach to protect their national policy space. In fact, it is surprising that most other countries concluding international investment agreements have not yet emulated this approach (and rapidly so) - in the interest of arriving at a different balance in the rights of host countries versus those of foreign investors and their foreign affiliates. The challenge is of course to find the right balance between the predictability that international investors require and the flexibility that host

178 See respectively <http://www.state.gov/s/l> and <http://www.international.gc.ca/trade -agreements-accords-commerciaux/topics-domaines/disp-diff/gov.aspx?lang=eng > accessed 14 September 2014.

See <http://www.state.gov/documents/organization/117601.pdf> accessed 14 September 2014; see also the 2012 United States BIT model <http://www.state.gov/documents/ organization/188371.pdf $>$ accessed 14 September 2014. For a comparison of the 1984 and 2004 US BIT models see Kenneth J Vandevelde, 'A Comparison of the 2004 and 1994 U.S. Model BITs: Rebalancing Investor and Host State Interests' in Karl P Sauvant (ed) Yearbook on International Investment Law \& Policy 20o8-20o9 (OUP 2009) 283-316; Alvarez (n 45).

180 Canada took a similar approach; see the 2004 Canadian Model BIT at Article 5 (defining 'fair and equitable treatment' as no more than the minimum of that required by customary international law) and Article 13 (prohibiting the expropriation of covered investments, 'except for a public purpose') <http://italaw.com/documents/Canadian2004-FIPA -model-en.pdf $>$ accessed 14 September 2014.

Trade Promotion Agreement, United States of America - Republic of Peru (signed 12 April 2006), Article 22.2, -footnote 2, signed on 12 April 2006, p. 22-1, <http://www.ustr.gov/ sites/default/files/uploads/agreements/fta/peru/asset_upload_file841_9542.pdf> accessed 29 September 2014.

THE JOURNAL OF WORLD INVESTMENT \& TRADE 16 (2015) 11-87 
country governments need to protect their own interests - and a self-judging essential security clause may go too far in this respect.

The other imbalance - between the responsibilities of foreign investors and their foreign affiliates versus those of host countries - is a more difficult matter, involving, as it does, prescriptions for the conduct of business entities. As discussed, the traditional home countries have been skeptical about, if not outright against, international guidelines for foreign investors and their foreign affiliates, at least if they are mandatory. While developing countries have taken the opposite approach in the past, it is quite conceivable that their attitude on this matter may change, as their own firms are becoming important foreign investors (see below). As a result, they may no longer be interested in binding guidelines for outward investors, but rather prefer voluntary ones. This is reflected by the fact that a number of emerging markets have adhered to the OECD Guidelines. ${ }^{182}$ Moreover, as the regulatory and judicial capacities of developing countries have become stronger and continue to improve, they are in a better position to deal with the negative effects of FDI and, more generally, any objectionable behavior of investors. In other words, they may no longer need, at least not as much in the past, the leverage of international agreements to deal with undesirable corporate behavior. In addition, home countries always have the possibility, at least to a certain extent, to impose unilaterally certain requirements on the TNCs outward-investing from their territories, be it on a voluntary basis, in exchange for an advantage or in a mandatory manner (although this may raise difficult issues related to the extra-territorial application of laws)..$^{183}$

182 Some countries, including China, may also be more interested in the potential reputational gains of the application of the Guidelines to their outward investors than in the application of the Guidelines to foreign investors in their territories. Communication by Manfred Schekulin (7 March 2014) (on file with the author).

For an example of the voluntary approach, see eg 'The Global Sullivan Principles' <http:// www1.umn.edu/humanrts/links/sullivanprinciples.html> and 'Promoting a European framework for Corporate Social Responsibility'<http://eur-lex.europa.eu/LexUriServ/Lex UriServ.do?uri=COM:2001:0366:FIN:en:PDF > accessed 29 September 2014. For an example of an exchange for an advantage, note that, eg the Overseas Private Investment Corporation of the United States requires that, for FDI projects to be eligible for its insurance, they need to meet certain criteria; see 'OPIC-supported projects should encourage positive host country development effects' <http://www.opic.gov/doing-business-us/OPICpolicies $>$ accessed 29 September 2014. For an example of the mandatory approach, see eg the United States Foreign Corrupt Practices Act, 15 USC $§ 78 \mathrm{dd}-1(\mathrm{a})(1)(\mathrm{A})(1977)<\mathrm{http}: / /$ www.justice.gov/criminal/fraud/fcpa/docs/fcpa-english.pdf $>$ (stating that ' $\mathrm{i}] \mathrm{t}$ shall be unlawful for any issuer..., or for any officer, director, employee, or agent of such issuer

THE JOURNAL OF WORLD INVESTMENT \& TRADE 16 (2015) 11-87 
Still, as the importance of TNCs in national economies and international economic transactions grows, it can be expected that the pressure for guidelines for international investors rises as well - greater (economic) power is likely to fuel calls for greater responsibilities, especially if egregious abuses should occur, not only in the global network of a given TNC, but also along the supply chain of individual TNCs. ${ }^{184}$ So far, this pressure has translated itself primarily into voluntary instruments, be it at the firm level (in the form of various corporate social responsibility commitments by individual firms), at the regional level (see e.g., the revitalized OECD Guidelines for Multinational Enterprises) or the most recent "Guiding Principles on Business and Human Rights," endorsed by the United Nations' Human Rights Council in 2011 (box 2). ${ }^{185}$ But it would be surprising if pressures not only continue, if not increase, for binding instruments - not, perhaps (as sought be the United Nations Code) in a single comprehensive undertaking, but in a series of instruments that, together, cover the most important issues relating to the rights and responsibilities of the principal commercial actors in the international investment process.

or any stockholder thereof acting on behalf of such issuer, to make use of the mails or any means or instrumentality of interstate commerce corruptly in furtherance of an offer, payment, promise to pay, or authorization of the payment of any money, or offer, gift, promise to give, or authorization of the giving of anything of value to... any foreign official for purposes of...(i) influencing any act or decision of such foreign official in his official capacity, (ii) inducing such foreign official to do or omit to do any act in violation of the lawful duty of such official, or (iii) securing any improper advantage') accessed 29 September 2014. The question of how far down in the supply chain the responsibility of parent/contracting firms reaches was an important topic in the 2011 OECD Guidelines review. See 'Multinational Enterprises: Better Guidelines for Better Lives' (2011) OECD Observer No 285 <http://www.oecdobserver.org/news/fullstory.php/aid/3553/Multinational_enterprises: _Better_guidelines_for_better_lives.html > accessed 29 September 2014, summarizing the main changes in the 2011 update. See also John Evans, 'Responsible Business Conduct: Re-shaping Global Business' (2011) 50 Columbia FDI Perspectives; Tadahiro Asami, 'Toward the Successful Implementation of the Updated OECD Guidelines for Multinational Enterprises' (2012) 56 Columbia FDI Perspective; and Inter-agency Working Group on the Private Investment and Job Creation Pillar of the G2o Multi-year Action Plan on Development, 'Promoting standards for responsible investment in value chains' (UNCTAD and others 2011).

Contained in the 'Guiding Principles on Business and Human Rights: Implementing the United Nations "Protect, Respect and Remedy Framework"' (United Nations Human Rights Office of the High Commissioner 2011).

For the status of implementation of the Guiding Principles, see Human Rights Council, 'Report of the Working Group on the Issue of Human Rights and Transnational Corporations and Other Business Enterprises', document A/HRC/26/25 (5 May 2014).

THE JOURNAL OF WORLD INVESTMENT \& TRADE 16 (2015) 11-87 


\section{BOX 2 Guiding Principles on Business and Human Rights [*]}

To some extent, the Guiding Principles can be seen as a follow-up to some of the United Nations Code and OECD Guidelines provisions (with the latter, as discussed earlier, closely linked with the United Nations Code). In fact, close interaction between the formulation of the Guiding Principles and the 2011 review of the OECD Guidelines ensured that the latter are compatible with the former. In the view of Manfred Schekulin, moreover, the OECD's National Contact Points 'are the closest existing thing to, and the best chance for, a properly functioning global implementation mechanism of the UN Guiding Principles' [a]. When issuing clarifications, the OECD's Investment Committee would of course mainly base itself on the text of the OECD Guidelines, but it may use the Guiding Principles as a secondary source.

This is not to say that the Guiding Principles (GP) do not have their own mechanisms. To quote John Ruggie, who, as the Special Representative of the SecretaryGeneral [of the United Nations] on the issue of human rights and transnational corporations and other business enterprises, steered the process of the preparation and adoption of the Guiding Principles: the main tasks of the Working Group on the issue of human rights and transnational corporations and other business enterprises established by the Human Rights Council 'are to promote the GPs' implementation and dissemination, identify and exchange good practices, help build the institutional capacity of developing countries as well as small and medium-sized enterprises, and provide further recommendations to the Council. The working group will conduct two official country visits a year, and also convene an annual global forum on business and human rights to examine overall trends and address challenges encountered in implementing the GPs. Along with the Office of the High Commissioner for Human Rights, the working group is also expected to play a role as the GPs' guardian, tracking how they are being interpreted by various actors. The working group, like the mandate before it, has adopted a multistakeholder approach and plans to work with diverse partners in different regions of the world' [b].

But, as Ruggie pointed out, the Guiding Principles - being, as they are, in a grey zone between voluntary and binding - go further: 'The Human Rights Council endorsed several propositions: that corporations have a responsibility to respect human rights; that respecting human rights means not infringing on the rights of others; and that the way to meet this responsibility is to have a risk-based human rights due diligence process. That authoritative statement of what these things mean and require made it easier (i) for other standard setting bodies to adopt the same principles (e.g., the OECD Guidelines, ISO26ooo); and (ii) for national authorities to adopt elements of the same principles as actual requirements, not just 
suggestions (export credit agencies have done so, for example; or the United States with a mandatory reporting requirement for investors in Myanmar). In the European Union, the Commission asked governments to submit national actions plans, which in some cases already include legal requirements. That was part of the strategy all along. So what we have got is a politically authoritative formula that in some instances is becoming hard law. Beyond that, the Guiding Principles of course also reaffirm the legal obligations of states with regard to business and human rights, and spell out in greater detail what this implies. Here, endorsement by the Council established a greater authoritative interpretation of existing obligations' [c].

Interestingly enough, there were further developments in the Human Rights Council (in 2014). More specifically, Ecuador and South Africa submitted the first draft of a resolution to the Council on 19 June 2014 (signed also by Bolivia, Cuba and Venezuela and supported by 20 countries) which, in its final version, directed the Council 'to establish an open-ended intergovernmental working group ... whose mandate shall be to elaborate an international legally binding instrument to regulate, in international human rights law, the activities of transnational corporations and other business enterprises' [d]. At the same time, Norway (supported by 22 other countries from all regions, including the members of the core group that had led the work on business and human rights since the beginning of the Special Representative's mandate) tabled a resolution that, in its final version, recognized 'that it may be further considered whether relevant legal frameworks would provide more effective avenues of remedy for affected individuals and communities' and requested the United Nations High Commissioner for Human Rights 'to continue work to facilitate the sharing and exploration of the full range of legal options and practical measures to improve access to remedy for victims of business-related human rights abuses' [e]. On 26 June 2014, the United Nations Human Rights Council voted in favor of Ecuador and South Africa's resolution, as follows: 20 in favor (Algeria, Benin, Burkina Faso, China, Congo, Côte d'Ivoire, Cuba, Ethiopia, India, Indonesia, Kazakhstan, Kenya, Morocco, Namibia, Pakistan, Philippines, Russia, South Africa, Venezuela, Vietnam), 14 against (Austria, Czech Republic, Estonia, France, Germany, Ireland, Italy, Japan, Montenegro, Republic of Korea, Romania, the Former Yugoslav Republic of Macedonia, United Kingdom, United States) and 13 abstentions (Argentina, Botswana, Brazil, Chile, Costa Rica, Gabon, Kuwait, Maldives, Mexico, Peru, Saudi Arabia, Sierra Leone, United Arab Emirates) [f]. On 27 June 2014, then, the Council adopted Norway's cross-regional resolution by consensus.

Note that the developed countries voted against the Ecuador and South Africa resolution, while a number of developing countries abstained. While it remains to be seen what will come of these efforts, it seems clear that developed countries continue to oppose binding behavioural rules for MNEs. While various nongovernmental organizations issued supportive statements $[\mathrm{g}]$, the International

THE JOURNAL OF WORLD INVESTMENT \& TRADE 16 (2015) 11-87 
Organisation of Employers (IOE) reacted by saying in a statement that it 'deeply regrets' that the adoption of the Ecuador/South Africa resolution 'has broken the unanimous consensus on business and human rights achieved three years ago with the endorsement of the UN Guiding Principles on Business and Human Rights'; that the vote is 'a genuine setback' to the efforts underway to improve human rights; and that the Human Rights Council has decided to 'return to approaches which have failed' in the past and which are 'diametrically opposed to the goal of quickly advancing the implementation' of the Guiding Principles (bold in the original) $[\mathrm{h}]$.

[*] For a discussion of this instrument, including its genesis, see John Gerard Ruggie, Just Business: Multinational Corporations and Human Rights (Norton and Company 2013). See also John Gerard Ruggie, “Global Governance and "New Governance Theory”: Lessons from Business and Human Rights' (2014) 20 Global Governance 5-17.

[a] Communication by Manfred Schekulin, 7 March 2014 (on file with the author).

[b] Ruggie (n 173).

[c] Communication by John Ruggie, 8 March 2014 (on file with the author).

[d] Human Rights Council, 'Elaboration on an International Legally Binding Instrument on Transnational Corporations and Other Business Enterprises with Respect to Human Rights' Resolution A/HRC/RES/9 (14 July 2014) para 1.

[e] Human Rights Council, 'Human Rights and Transnational Corporations and Other Business Enterprises' Resolution A/HRC/RES/26/22 (15 July 2014) Declarative para 11 and para. 7 .

[f] See Business and Human Rights Resource Center, UN Humanitarian Council Cessions, $<$ http://business-humanrights.org/en/binding-treaty-pros-and-cons/un-human-rights -council-sessions> accessed 6 August 2014. See also the commentary by John Ruggie, 'Quo vadis? Unsolicited Advice to Business and Human Rights Treaty Sponsors' < http://www.ihrb .org/commentary/quo-vadis-unsolicited-advice-business.html> accessed 5 October 2014.

[g] See <http://business-humanrights.org/en/binding-treaty/un-human-rights-council -sessions $>$ accessed 12 September 2014.

[h] See International Organisation of Employers, 'Consensus on Business and Human Rights is Broken with the Adoption of the Ecuador Initiative' <http://www.ioe-emp.org/index .php?id=1238> accessed 12 September 2014.

\section{$7 \quad$ What Could Bring About Change?}

What could lead to a more profound change toward a more balanced international investment law and policy regime? Short of a catalytic event like the end of World War II that had led to the establishment of the Bretton Woods institutions, ${ }^{186}$ there are many drivers for change. ${ }^{187}$ They include the realization that,

\footnotetext{
186 The point made by $\operatorname{Karl}$ ( $\mathrm{n} 173)$.

187 For a discussion, see Sauvant and Ortino (n 177).
} 
once the regulatory framework for FDI is enabling (and becomes quite similar across countries), international investment agreements do not necessarily lead to more FDI, given that economic factors are paramount in investment decisions; that the expectations of governments regarding the desirability of FDI are changing, especially as far as mergers and acquisitions are concerned; that the number of treaty-based investment disputes is rising, with potentially substantial financial costs for host countries (both in terms of litigating the disputes and paying awards if they loose); and pressures from civil society at the national and international levels to arrive at a different international framework for international investment, including one that takes sustainable development considerations into account.

But none of these factors in and of itself is as important as (1) the rise of emerging markets as important FDI home countries; and (2) developed countries becoming respondents in treaty-based international investment disputes, and hence more conscious about their status as host countries.

The rise of emerging market TNCs is indeed impressive. As mentioned earlier, there are now at least 30,000 TNCs headquartered in emerging markets. FDI outflows from these economies ${ }^{188}$ averaged about $2 \%$ of a rough annual average of USD 50 billion world FDI outflows during 1980-1985, compared to $39 \%$ of USD 1.4 trillion world FDI outflows during $2013 .{ }^{189}$ In absolute amounts, FDI outflows from emerging markets had risen from about USD 1 billion during 1980-1985, to USD 553 billion in 2013 - the latter figure being more than ten times world outflows three decades ago when the United Nations Code negotiations were still in an active phase. Since 2004, outward FDI flows from emerging markets have been over USD 100 billion annually. TNCs from these countries are now important players in the word FDI market.

As a result, not surprisingly, the interest situation of emerging markets is changing as well. Nowhere is this more clearly visible than in the evolution of China's BITs (and China has more of such treaties than any other country, bar Germany). While China's early BITs clearly reflected its position as a host country (visible in, e.g., the limited application of national treatment and investorstate dispute settlement and her adamant opposition to pre-establishment national treatment), ${ }^{190}$ the situation has changed profoundly since then, and

\footnotetext{
188 All economies not defined as 'developed economies' in UNCTAD's World Investment Report.

189 See respectively United Nations (n 28) and UNCTAD (n 146) annex table 1.

190 Valentina Vadi, 'Converging Divergencies: The Rise of Chinese Outward Foreign Investment and its Implications for International (Investment) Law' in Karl P Sauvant (ed), Yearbook on International Investment Law \& Policy 2011-2012 (OUP 2012) 705-724.
} 
the country's IIAs have become quite similar to those of the traditional principal capital exporters. ${ }^{191}$ If one wanted to pinpoint the precise date at which China's home country interests became equal to, or more important than, its host country interests, one might point to 11 July 2013, when China agreed, in the context of the United States-China Strategic and Economic Dialogue, to continue negotiations of a BIT with the United States on the basis of preestablishment national treatment and the negative list approach to exceptions to such treatment. ${ }^{192}$ With the rise of China as an outward investor, its interests as a host country to protect its policy space have increasingly been complemented by its interests as a home country to protect the investments of her firms abroad and facilitate their operations. More generally, with the rise of emerging markets as outward investors, the international investment problematique is increasingly loosing the North-South dimension that characterized it during the 1970 and 1980 .

At the same time, developed countries have increasingly become respondents in international investment disputes. Investor-state dispute-settlement clauses were incorporated as the BITs movement gathered pace ${ }^{193}$ (concluded at that time only between developed and developing countries), because foreign investors did not trust the legal systems of developing countries. Moreover, it was assumed that only governments of developing countries would be respondents, including because there was little outward FDI from these countries. The situation changed in the 1990s when NAFTA's dispute-settlement mechanism led to a number of disputes that had the United States and Canada as respondents. More generally, by the end of 2013 and among developed countries, only the Czech Republic (20 cases) had a similar cumulative number of

191 ibid. Or, to quote, Schill, the new generation of China's BITs (starting with the BIT with The Netherlands (2001) and Germany (2003)) 'conform, despite some remaining limitations, in all major aspects to what can be considered standard treaty practice in approximately 2,500 BITs world-wide', turning the country's BITs 'into effective and powerful tools of investment protection'. See Stephan W Schill, 'Tearing Down the Great Wall: The New Generation Investment Treaties of the People's Republic of China' (2007) 15 Cardozo $\mathrm{J}$ Intl \& Comp L 76-77. See also Norah Gallagher and Wenhua Shan, Chinese Investment Treaties: Policies and Practice (OUP 2009).

192 Xinhua, 12 July 2013. In making this important policy change, it might well be that internal policy considerations - in particular its implications for domestic economic reform were equally important.

193 The 1968 BIT between The Netherlands and Indonesia was the first such treaty to incorporate a provision for investor-state dispute settlement (following the entry into force of the ICSID Convention); during the 1990s, this approach became generally adopted. See Vandevelde (n 46) 431.

THE JOURNAL OF WORLD INVESTMENT \& TRADE 16 (2015) 11-87 
disputes in 2013 as the United States ${ }^{194}$ and Canada; of the 514 treaty-based investor-state disputes known at the end of 2012, 120 had an OECD member as a respondent. ${ }^{195}$

This rise of treaty-based investment disputes testifies to the usefulness (from the point of view of investors) of the dispute-settlement mechanism in dealing with alleged treaty violations. It also underlies, as the earlier Wälde quote suggests, the strength of the international investment law and policy regime. But it puts all treaty partners, including developed countries, on notice that they are not immune from disputes and that there are potentially substantial monetary consequences, both in terms of litigating disputes and the awards that may be rendered. The fact that developed countries are by far the most important host countries for foreign investors, combined with the great number of TNCs and their foreign affiliates, as well as applicable BITs and other IIAs (and a broad definition of what constitutes an 'investment'), provides the basis for a great number of potential disputes (involving of course not only governments of developed countries but also developing ones). As a consequence, and as mentioned earlier, at least some developed countries (led by the United States and Canada) have begun to circumscribe key protections enshrined in IIAs to reduce the likelihood that they could become respondents in international investor-state disputes. Moreover, it may also be possible that more developed countries, as well as emerging markets, will reserve for themselves certain interpretive powers of treaties in order to be able to intervene in disputes should they arise.

These two developments - the rise of emerging markets as important FDI home countries and developed countries becoming respondents in treatybased international investment disputes (and hence more conscious about their status as host countries) - are the most important current drivers for change in the international investment law and policy regime. Reflecting the changing interest situations of countries, a new balance between the role of international investment law and national regulation in governing the operations of international investors and their investments is emerging.

194 It should be noted that the United States has not yet lost a case brought against the country.

195

Using the OECD country list <http://www.oecd.org/about/membersandpartners/list-oecd -member-countries.htm > accessed 4 September 2014 and data from UNCTAD (n 168) annex 2. Note that the number of disputes may actually be higher; see Luc Eric Peterson, 'Analysis: Why it's Important to Read Between the Lines of UNCTAD's Annual Review of Investor-State Dispute Settlement Cases' (12 May 2014) Investment Arbitration Reporter <http://www.iareporter.com/articles/20140512> accessed 4 September 2014.

THE JOURNAL OF WORLD INVESTMENT \& TRADE 16 (2015) 11-87 
In the future, moreover, another driver may become important, a recognition that was already present at the beginning of the United Nations Code effort, namely that the very global nature of TNCs calls for a multilateral approach. While there is certainly substantial overlap between the interests of foreign investors and host countries (which is, after all, the basis on which governments seek to attract FDI), ${ }^{196}$ the fundamental interests of TNCs and national governments do not always coincide. More specifically, although the foreign affiliates of individual TNCs are separate legal entities established in many jurisdictions, they nevertheless are under the common governance of their parent firms - and parent firms seek to maximize their global competitiveness, not the competitiveness of any one of their individual foreign affiliates. Governments, on the other hand - be they governments of host or home countries - seek to maximize the national benefits associated with FDI, i.e., the benefits that can be realized within their territories. This implies that the global operations of firms call for an equally global regime. The fundamental difference in the benefits frame of reference regarding the respective objectives of TNCs and governments is likely to become even more pronounced as firms become more multinational, i.e., the more their assets are distributed across countries.

Therefore, even home countries will increasingly face the dilemma that, what is good for, say, GM, Siemens, Lenovo, and Tata is not necessarily always good for their respective home countries, the United States, Germany, China, and India. The discussions conducted by the OECD and the G2o on how to deal with tax avoidance by TNCs indicate that key countries have recognized, at least for one area, that a global phenomenon requires a 'global response.' ${ }^{197}$

196 This overlap is defined primarily by the interest of governments in obtaining access to the tangible and intangible assets that TNCs control that are important for economic growth and development (with negative effects being minimized) and the interest of TNCs in the locational advantages of host countries. Policies play an important role in enhancing and increasing that overlap.

197 See the G-20 'Communique', Meeting of Finance Ministers and Central Bank Governors (22-23 February 2014) para 9 <http://www.g20.org/sites/default/files/g20_resources/ library/Communique\%2oMeeting\%20of\%2oG20\%2oFinance\%2oMinisters\%2oand\%2o Central\%2oBank\%2oGovernors\%2oSydney\%2022-23\%2oFebruary\%202014_o.pdf> accessed 29 September 2014, See also George Osborne, Pierre Moscovici and Wolfgang Schäuble (respectively Ministers of Finance of the United Kingdom, France and Germany), 'We Are Determined that Multinationals Will Not Avoid Tax' Letter to the Editor, Financial Times (16 February 2013).

THE JOURNAL OF WORLD INVESTMENT \& TRADE 16 (2015) 11-87 
If it is accepted that a global phenomenon requires a global response, and that this response needs to reflect the principal interests of all major stakeholders, then the fundamental issues that were put on the international agenda some 40 years ago in the context of the United Nations Code discussions are still with us today. If anything, the issues have become more salient, given the expansion of the number of TNCs and the considerable growth of FDI. To be sure, substantial progress has been made since then, not only in understanding the nature and impact of TNCs and their foreign investments, but also through a proliferation of various instruments applicable to them. But a comprehensive overarching framework has eluded us so far, a framework governing international investment as the most important vehicle for bringing goods and services to foreign markets and integrating the production systems of individual economies.

What can we learn from the experience of the United Nations Code negotiations, as well as the negotiations of related instruments, for the establishment of such a framework?

To begin with, any effort to negotiate a comprehensive multilateral instrument that defines in a balanced and binding manner the rights and responsibilities of countries and TNCs on all important issues related to international investment, contained in a rational structure, requires careful preparation before actual negotiations begin. In the words of the Chair of the Working Group of the United Nations Code of Conduct: 'Never launch an initiative of this complexity and magnitude without sufficiently long and thorough preparations. ${ }^{198}$ While the lack of such preparations was not decisive for the eventual failure of the United Nations Code negotiations (after all, governments had largely agreed on the guidelines part of the draft, and they had reached consensus on the OECD, ILO and UNCTAD instruments), it was an issue when it came to the more specific and technical treatment provisions. Negotiators need to be fully aware of the myriad of difficult technical issues involved, the advantages and disadvantages of various trade-offs, the implications key provisions have for their national policy-making, the costs of violating provisions of any agreement, etc., etc. In fact, such a preparatory process would be advisable for the negotiation of any international investment instrument, and it must be a process that is transparent and involves the range of stakeholders in this area. ${ }^{199}$

\footnotetext{
198 Sten Niklasson, communication dated 25 February 2014 (on file with the author).

199 A prime example here is the process that led to the adoption of the 'Guiding Principles for Business and Human Rights' (n 185). In a broad and extensive program of stakeholder
} 
Moreover, any effort of this complexity and magnitude may simply be too ambitious an objective in today's environment. ${ }^{200}$ To be sure, a comprehensive instrument provides more scope for trade-offs. ${ }^{201}$ But it also requires that the interests of all principal stakeholders need to be accommodated across a wide area of issues. Today, this is more difficult than it was 40 years ago. At that time, the principal stakeholders were governments, TNCs and trade unions. Today, one needs to add other vested interests, including practitioners of international investment law (i.e., the international investment arbitration profession), parliamentarians and various non-governmental organizations (consisting of countless interest groups that are focused on various aspects of the problematique, ranging from groups particularly interested in the development impact of FDI to anti-smoking groups). Huge economic and political interests are at stake. Reaching consensus is also difficult because new issues have arisen since the time the United Nations Code negotiations had begun, broadening the scope of negotiations and increasing the complexity of the subject matter on which agreement needs to be reached. ${ }^{202}$ These new issues range from such specific matters as abusive treaty shopping or whether stateowned enterprises need special rules; to the question of where the boundaries are of individual firms (especially in regard to supply chains) and the functioning of the investor-state dispute-settlement mechanism; to such fundamental issues as to whether the purpose of the investment regime requires a reorientation toward sustainable international investment. ${ }^{203}$

consultations, support and buy-in were created. This was done through a great number of international consultations on all continents. Furthermore, the Special Representative and his team visited business operations and local stakeholders in a number of countries. In addition, some of the principles were 'road-tested' through pilot programmes, for example, to establish effectiveness criteria for non-judicial grievance mechanisms involving business enterprises and communities.

200 See in this context the failed negotiations within the OECD of a Multilateral Agreement on Investment and the so far unsuccessful effort to deal with international investment in the WTO.

201 A consideration that has been important, under the heading of 'a single undertaking', in WTO negotiations. But see Baldi (n 141) on having too broad an agenda.

202 On the other hand, some issues that bedevilled the United Nations Code negotiations are no longer relevant today, eg the question of apartheid in South Africa.

203 Defined as FDI that makes a maimum contribution to the economic, social and environmental development of countries and takes place within the framework of fair governance mechanisms (eg in the case of contracts). For an early effort to re-orient international investment treaties toward sustainability, see the model treaty prepared by the International Institute on Sustainable Development: Howard Mann and others, IISD Model International Agreement on Investment for Sustainable Development (IISD 2006)

THE JOURNAL OF WORLD INVESTMENT \& TRADE 16 (2015) 11-87 
On the other hand, the rapid adoption of the OECD Guidelines, the ILO Tripartite Declaration and the UNCTAD Restrictive Business Practices Set - all three negotiated in the shadow of the beginning United Nations Code effort suggests that it may be easier to focus on specific aspects of the problematique, with a manageable agenda - in other words, to negotiate issue-specific instruments, be they focused on treatment issues, ${ }^{204}$ guidelines or any other aspect related to international investment. In such circumstances, a more limited range of interests is typically involved, and stakeholders may be more forceful and focused in moving the negotiations forward. ${ }^{205}$ However, all three instruments mentioned at the beginning of this paragraph are voluntary. Moreover, the OECD Guidelines were part of a package that involved treatment provisions and were negotiated within a group of like-minded countries. Still, these three instruments represent the principal concrete legacy of the United Nations Code effort, apart, of course, from having brought the issue prominently and permanently on the international agenda and having helped to clarify many of the key issues involved (which was of use, too, for negotiators of subsequent international investment agreements).

Regardless of whether the objective is a comprehensive multilateral or an issue-specific instrument, there is the difficulty of obtaining consensus among all governments, be it in the United Nations, the WTO or any other global institution. This is certainly more of a challenge today than 40 years ago, if only because the number of governments involved has risen considerably. ${ }^{206}$ If a comprehensive multilateral agreement is deemed too difficult, this raises the

<http://www.iisd.org/pdf/2005/investment_model_int_handbook.pdf> accessed 29 September 2014. More recently, UNCTAD has pursued this issue through its Investment Policy Framework for Sustainable Development; see UNCTAD, World Investment Report 201 2: Towards a New Generation of Investment Policy (UNCTAD 2012) ch IV.

The voluntary World Bank 'Guidelines on the Treatment of Foreign Direct Investment' finalized in 1992, are an example here, see World Bank Report to the Development Committee and Guidelines on the Treatment of Foreign Direct Investment, 21 September 1992, published as Legal Framework for the Treatment of Foreign Direct Investment (volume II, Guidelines) (World Bank 1992). This instrument does not contain mechanisms for follow-up or implementation.

Specific issues addressed in the United Nations Code later became the subject of separate instruments; see eg the earlier mentioned 'Guiding Principles on Business and Human Rights: Implementing the United Nations "Protect, Respect and Remedy Framework"' (n 185).

The Working Group on the Code had 48 members, although others could join. When the negotiations moved into the Special Session of the Commission on Transnational Corporations, the meetings were formally open to all United Nation members, although not many participated actively in the negotiations.

THE JOURNAL OF WORLD INVESTMENT \& TRADE 16 (2015) 11-87 
question of whether a plurilateral or regional approach should be pursued, an approach in which a significant number of committed key players begin negotiations and invite others to join if and when they are ready to do so. ${ }^{207}$

The OECD, ILO and UNCTAD instruments also show the importance of mutual self-interest, pressure that 'something needs to be done' and political will. As discussed earlier, initially there was considerable pressure on governments, as well as common self-interest (even if for different reasons) to take action when these three instruments were negotiated, creating the political will to enter negotiations. But even then, there needs to be sufficient overlap of interest between key players in order to move the process forward and to a successful conclusion. However, as the United Nations Code negotiations showed (which also began under conditions of overlapping interest, pressure and political will), it is difficult to maintain political will and overlapping interest over time, especially when circumstances change, pressure dissipates and the general consensus about the overall objectives of the negotiations (guidelines and treatment) is fragile. The iron needs to be struck while it is hot - which was done in the case of the instruments mentioned at the beginning of this paragraph.

Furthermore, even if an instrument is voluntary, its scope, content, implementation mechanism, and standing can be strengthened over time. This was the case for the OECD Guidelines, through the availability of a clarification mechanism, the strengthening of the implementation mechanism, the opening up of the implementation mechanism to other interested parties (such as non-governmental organizations), and the expansion of topics covered. In the case of the ILO Declaration, an implementation mechanism was agreed upon after the original instrument was adopted and cross-references to new instruments negotiated in the framework of the ILO (e.g., on core labor standards) were added, expanding the reach of this particular instrument. (In the case of the UNCTAD Set, however, these possibilities were not, and could not be, utilized.) While this does not change the voluntary character of an instrument, it can make it more effective. ${ }^{208}$ Moreover, even voluntary instruments can be

207 Gary Hufbauer and Sherry Stephenson are among those who advocate a plurilateral approach; see their 'The Case for Case for a Framework Agreement on Investment' (2014) 116 Columbia FDI Perspective. They also suggest that such an agreement be negotiated in the WTO and that, at one point, the rights enshrined in such an agreement could be extended to all WTO members. It would be a plurilateral process that could result in a multilateral outcome.

208 In some countries, eg the United States, voluntary instruments, as soft law, can potentially be used in courts against firms; see also (n 109).

THE JOURNAL OF WORLD INVESTMENT \& TRADE 16 (2015) 11-87 
strengthened, e.g., by referring to them in binding international agreements. ${ }^{209}$ Finally, standards agreed to at the international level, even if voluntary, can become hard law in a national context, as happened, e.g., with the Dodd Frank due diligence process provisions on conflict minerals in the United States, ${ }^{210}$ which are based on the OECD voluntary due diligence instrument. ${ }^{211}$ This also suggests that, to whatever extent voluntary instruments exist, they should be used to the fullest extent possible.

Thus, the availability and strength of an implementation (or follow-up) mechanism becomes crucial to making an instrument effective, as absent such a mechanism, a text alone risks becoming worthless. Follow-up can consist of a review of an instrument in regular intervals, as in the annual discussions of the ILO Tripartite Declaration and the review conferences of the UNCTAD Set that takes place every five years. A review can also take place in irregular

209 This was considered in the context of the OECD's negotiations of a Multilateral Agreement on Investment (when the proposal was made to annex the OECD Guidelines) and has happened, for instance, in the case of a reference to the OECD Guidelines in the Preamble of the 2014: 'Abkommen zwischen der Republik Österreich und der Republik Tadschikistan über die Förderung und den Schutz von Investitionen' stating, 'MIT DEM AUSDRUCK des Glaubens, dass verantwortungsvolles unternehmerisches Handeln wie es in den OECDRichtlinien für multinationale Unternehmen enthalten ist, zum wechselseitigen Vertrauen zwischen Unternehmen und Gastgeberstaaten beitragen kann.' See <http:// www.bmwfw.gv.at/Aussenwirtschaft/investitionspolitik/Documents/BGBLA__2012 _III_18_Text.pdf> accessed 15 September 2014. The recently negotiated BIT between The Netherlands and the United Arab Emirates contains a reference to the OECD Guidelines, the first such express reference in a Dutch BIT; see <http://www.loyensloeff.com/en-US/ News/Publications/Newsletters/DubaiNewsflash/Dubai_flash_26nov.pdf> accessed 15 September 2014. Similarly, the Netherlands-United Arab Emirates BIT (while not yet ratified) provides:

'Article 2: Promotion of Investments: ... (3) Each Contracting Party shall promote as far as possible and in accordance with their domestic laws the application of the OECD Guidelines for Multinational Enterprises to the extent that is not contrary to their domestic laws.' See <http://wetten.overheid.nl/BWBVooo6303/geldigheidsdatum_24-04-2014> accessed 15 September 2014.

See Dodd-Frank Wall Street Reform and Consumer Protection Act, Pub. L 111-203, 124 Stat 1376 (21 July 2010) Section 1502.

211 OECD, Due Diligence Guidance for Responsible Supply Chains of Minerals from Conflictaffected and High-risk Areas (2nd edn, OECD 2013). The recent European Commission proposal concerning conflict minerals is even more explicitly based on the OECD due diligence guidance; see European Commission, 'Proposal for a Regulation of the European Parliament and of the Council Setting up a Union System for Supply Chain due Diligence Self-certification of Responsible Importers of Tin, Tantalum and Tungsten, Their Ores, and Gold Originating in Conflict- affected and High-risk Areas' COM (2014) 111 final.

THE JOURNAL OF WORLD INVESTMENT \& TRADE 16 (2015) 11-87 
intervals, as in the case of the OECD Guidelines. During reviews, questions can be raised and the observance of an instrument can be discussed. The follow-up is stronger if a dedicated body has been established with the mandate to clarify issues that arise under the instrument, as was done in the case of the OECD and (although less effectively) in the cases of the ILO Tripartite Declaration. Moreover, an implementation mechanism can be upgraded over time, as in the case of the OECD Guidelines through the strengthening of the role of the National Contact Points; among other things, these 'assist enterprises and their stakeholders to take appropriate measures to further the implementation of the Guidelines.' ${ }^{212}$ It was their implementation mechanisms, developed over time in the case of the OECD Guidelines, as well as the active work of the ILO and UNCTAD secretariats, that made these instruments relatively effective by establishing forums for discussion and creating institutional homes and selfinterest on the part of the organizations involved, including to promote the use of the respective instruments.

A crucial ingredient making the voluntary OECD (and ILO) instruments relatively effective was that key constituencies, in these cases particularly trade unions, had access to the implementation mechanisms of both organizations in order to present cases/issues that involved possible violations of what had been agreed upon. In the case of the ILO Tripartite Declaration, workers' representatives played the key role. In the case of the OECD Guidelines, the majority of cases/issues initially brought for clarification were tabled by trade unions (governments did not raise issues that often). Moreover, eventually non-governmental organizations obtained access to the OECD's implementation mechanism and used this access fully. Non-governmental organizations made these two instruments, and especially the OECD Guidelines, 'living instruments'. Hence, access by key stakeholders to the implementation mechanism of any voluntary instruments agreed upon is likely to help ensure the effectiveness of these instruments.

It appears appealing to seek to negotiate a binding comprehensive multilateral instrument that, in a balanced manner, addresses the rights and responsibilities of all major stakeholders on all important issues related to international investment, contained in a rational structure. But, absent a catalytic event, a grand design of this nature may be a bridge too far (for the reasons mentioned earlier) in the foreseeable future. The more likely approach to

212 OECD $\left(\mathrm{n}_{57}\right)$. The National Contact Points also 'provide a mediation and conciliation platform for resolving practical issues that may arise' ibid. Not all national contact points are necessarily equally active.

THE JOURNAL OF WORLD INVESTMENT \& TRADE 16 (2015) 11-87 
succeed - already successfully pursued at the beginning of the United Nations Code negotiations - may be an issue-specific approach, a pragmatic approach to seek agreement on aspects of the regulatory framework governing TNCs and their activities for which there is shared self-interest, pressure and political will, in whatever forum that is most promising. Progress could be sought both regarding the treatment and guidelines aspects of a comprehensive regulatory framework. Part of such an approach could also be to seek a 'hardening' of soft law (i.e., voluntary) instruments; the OECD Guidelines are a case in point, ${ }^{213}$ covering, as they do, over four-fifth of the world's FDI stock. ${ }^{214}$ Even if the resulting instruments are not perfect, they provide a platform on which further agreement can be built, especially if there is a strong implementation mechanism that also provides access to non-governmental groups.

Such an approach can also benefit from what appears to be a somewhat cyclical nature of rule making regarding international investment, with the pendulum swinging sometimes in favor of one type of instrument and at other times in favor of another type. ${ }^{215}$ Thus, during the 1970 s and at the beginning of the 1980s, the watchword was 'control', while during the later 1980 s and the 1990s, the watchwords were 'liberalization' at the national level and 'protection' at the international level. Since 2000, national policies have become more

213 See Roel Nieuwenkamp, 'The OECD Guidelines for Multinational Enterprises on Responsible Business Conduct: Soft Law with Hard Consequences' (2013) Dovenschmidt Quarterly 171-175. See also Roel Nieuwenkamp and Kimmo Sinivuori, 'The Road to Responsible Investment Treaties' Columbia FDI Perspective (forthcoming), as well as the examples given earlier (n 209), regarding the references to the OECD Guidelines in BITs. For a discussion of the relationship between soft law and international investment law, see Andrea Bjorklund and August Reinisch (eds), International Investment Law and Soft Law (Edward Elgar 2012), and for the relationship between corporate social responsibility commitments and trade and investment rules, Christopher Wilkie, 'Enhancing Global Governance: Corporate Social Responsibility and the International Trade and Investment Framework' in John J Kirton and Michael J Trebilcock (eds), Hard Choices, Soft Law: Voluntary Standards in Global Trade, Environment and Social Governance (Ashagate Publishing 2004) 288-319.

214 'In terms of FDI, this means that USD 19 trillion of the USD 23 trillion of global FDI stocks $(83 \%)$ is covered by the OECD Guidelines because the MNEs that own this FDI are based in adherents to the Guidelines.' Communication by Michael Gestrin (24 March 2014) (on file with the author).

Following Karl Polanyi (The Great Transformation (Beacon Press 1944)), Alvarez suggested that the United States 1984 Model BIT might embody the high-point of a liberal laissezfaire approach to international investment rule making, creating a counter-movement toward more balanced IIAs. Alvarez (n 45) 640.

THE JOURNAL OF WORLD INVESTMENT \& TRADE 16 (2015) 11-87 
nuanced, ${ }^{216}$ while international instruments consisting of guidelines have been strengthened ${ }^{217}$ and new ones have been added, ${ }^{218}$ and some international investment agreements have become more cautious ${ }^{219}$ while also aiming for more liberalization. ${ }^{220}$

Rule making may therefore be haphazard, messy and uneven, depending on what is needed and what is feasible in a given constellation of interests and forces. But, hopefully, an overall regime is put in place over time that, through the combination of various instruments, adds up to a regime that covers, comprehensively and in a balanced manner, the various aspects of the range of issues related to international investment.

This also applies to the question of whether such rule making should take place in a multilateral, plurilateral, regional, or bilateral context - it all depends on what is feasible. For example, there is the possibility of a convergence of bilateral and regional approaches given that, in 2014, a number of investment treaty negotiations were underway (or were considered), involving key developed and developing countries. At the bilateral level, these included in particular the negotiations of BITs between China and the United States and between China and the European Union; the negotiations between the European Union and India and the European Union and Japan; the European Union-United States negotiations of a Transatlantic Trade and Investment Partnership; and the negotiations between India and Japan and India and the United States. At the regional level, the most prominent negotiations concern the Trans-Pacific Partnership agreement (involving key countries in the Pacific) and the Regional Comprehensive Economic Partnership Agreement in Asia (involving the ASEAN countries, as well as Australia, China, India, Japan, New Zealand, and the Republic of Korea). ${ }^{221}$ With some exceptions, ${ }^{222}$ these negotiations involve the principal players in the world FDI market.

216 This is reflected in the number of national policy changes related to FDI that make the regulatory framework less welcoming for such investment, as reflected, eg in the creation of screening mechanisms for national security purposes.

217 The OECD Guidelines discussed earlier.

218 See eg the 'Guiding Principles...'(n 185).

219 See eg the changes in the 2004 United States Model BIT discussed in Álvarez (n 45) and Vandevelde (n 179).

220 In particular by including pre-establishment commitments.

221 See in this context Schill (n 11).

222 Most notably, Brazil has not ratified any of the BITs it has negotiated, and South Africa has virtually stopped negotiating BITs, while terminating some existing ones, and putting in place a new domestic regulatory framework; see Xavier Carim, 'Lessons from South Africa's BITs Review' (2013) 109 Columbia FDI Perspectives.

THE JOURNAL OF WORLD INVESTMENT \& TRADE 16 (2015) 11-87 
It can be assumed, at least to a certain extent, that the negotiating parties will seek a certain degree of consistency in their various commitments in different instruments (if only because most of them are likely to include a mostfavored-nation clause), providing the basis and a framework for future negotiations worldwide. If this were indeed the case, bilateral and regional approaches could coalesce in a plurilateral or multilateral regime in at least one area, the treatment of international investors and their foreign investments. ${ }^{223}$ Particularly important here are the BIT negotiations between China

223 Furthermore, it is not inconceivable that a new WTO agenda includes investment. The WTO already has a number of instruments bearing on international investment, notably the General Agreement on Trade in Services (GATS) <http://www.wto.org/english/ docs_e/legal_e/26-gats.pdf> accessed 29 September 2014 and the Agreement on Traderelated Investment Measures (TRIMs) < http://www.wto.org/english/docs_e/legal_e/ 18-trims.pdf $>$ accessed 29 September 2014.

In a report to the ICC Research Foundation, released in April 2013, the authors observed that 'the WTO can do useful work preparing the ground for a multilateral framework' for investment; see Gary Hufbauer and Jeffrey Schott, Payoff from the World Trade Agenda 2013 (Peterson Institute for International Economics 2013) 50. Additionally, during April 2013, the International Chamber of Commerce adopted during its 2013 World Trade Agenda Summit in Doha its 'Business Priorities'. This agenda included as one of five priorities, in a section that looked beyond the WTO Doha Round, the following recommendation: 'Encourage moving towards a high-standard multilateral framework for international investment to support economic growth and development, while preserving the level of protection provided under existing international agreements'. See ICC, 'Business Priorities' <http://www.iccwbo.org/Advocacy-Codes-and-Rules/Document-centre/1999/ World-business-priorities-for-a-new-round-of-multilateral-trade-negotiations/> accessed 29 September 2014. Also, the World Economic Forum Global Agenda Council on Trade and Foreign Direct Investment released, in June 2013, a report entitled 'Foreign Direct Investment as a Key Driver for Trade, Growth and Prosperity: The Case for a Multilateral Agreement on Investment' (WEF 2013) which, as its title indicates, calls for a multilateral agreement on investment. Similarly, the National Foreign Trade Council of the United States (a business organization) proposed (according to Inside US Trade, 21 February $2014,8)$ 'that WTO members negotiate a clear set of investment rules that would apply across countries and be less confusing for investors than the "large and growing patchwork of Bilateral Investment Treaties [BIT]"' These statements seem to signal that the international business community, a key stakeholder, is in support for a multilateral framework for investment, albeit only as far as treatment issues are concerned.

See also Anabel Gonzales, 'The Rationale for Bringing Investment into the WTO' in Simon J Evenett and Alejandro Jara (eds), Building on Bali: A Work Programme for the WTO (Centre for Economic Policy Research 2013) 67-80; Anders Åslund, 'The World needs a Multilateral Investment Agreement' (2013) Policy Brief No PB13-01. Others argue that a multilateral instrument is not likely. See for example Axel Berger, 'The Futile Debate over

THE JOURNAL OF WORLD INVESTMENT \& TRADE 16 (2015) 11-87 
and the United States, as China is the single largest host and home country among developing countries, while the United States occupies the same position among developed countries. If these two countries should be able to agree on a text, even if not ratified in the end, it would be a historic compromise that might well provide a template for other negotiations. ${ }^{224}$

Furthermore, rule making in such a scenario would be incremental, seeking not only to do what is needed and feasible, but also building on what has already been done. An incremental approach, for its part, could involve a series of activities that range from increasing understanding and confidence building, to seeking to identify specific improvements that interested treaty partners could adopt. ${ }^{225}$ More specifically, such activities could include: ${ }^{226}$

- Fact-finding, e.g., international hearings on the investment regime; a restatement of international investment law.

- Dialogue roundtables between business and civil society.

- Consensus-building working groups on substantive issues, e.g., the investment regime's purpose, how sustainable international investment considerations could be incorporated into international investment agreements, the contents of norms (including the question of the extent to which investors should assume certain responsibilities), treaty shopping; and procedural issues (e.g. (and most importantly), dispute settlement).227

- A model bilateral investment treaty.

- Specific mechanisms to improve the current investment regime, e.g., an FDI protectionism observatory; a negotiating support facility to help developing

a Multilateral Framework for Investment' (2013) 102 Columbia FDI Perspective <http:// ccsi.columbia.edu/files/2014/o1/FDI_102.pdf > accessed 14 September 2014; and Karl (n 173).

224 See Karl P Sauvant and Huiping Chen, 'A China - US Bilateral Investment Treaty: A Template for a Multilateral Framework for Investment?' (2012) 85 Columbia FDI Perspective <http://ccsi.columbia.edu/files/2014/o1/FDI_85.pdf> accessed 14 September 2014. The same might emerge from the negotiations of the Trans-Pacific Partnership and the Transatlantic Trade and Investment Partnership; but since China, as the most important home and host country among developing countries, is not party to these negotiations, these negotiations may, in the end, fall short of a global model.

225 It is interesting to note that the preparations of the 'Guiding Principles for Business and Human Rights' took an incremental approach in the framework of which the Special Rapporteur undertook an extensive programme of stakeholder consultations to gather support and buy-in (as described earlier).

226 For an elaboration of the following, see Sauvant and Ortino (n 177).

227 Some of this work is already ongoing, in the respective committees of UNCTAD and the OECD.

THE JOURNAL OF WORLD INVESTMENT \& TRADE 16 (2015) 11-87 
countries (and especially the least developed among them) negotiate equitable large-scale, complex contracts between them and foreign investors (and, in this manner, also reduce the likelihood that disputes arise); ${ }^{228}$ an advisory center on international investment law that would help developing countries (and especially the least developed among them) defend themselves in international investment disputes (ensuring in this manner that they benefit as much from the international investment regime as countries that are better resourced); and a recourse mechanism for a wider set of stakeholders.

Such an incremental process could also identify 'low-hanging fruits' (i.e., specific issues that command broad agreement on the need to tackle them, e.g., abusive treaty shopping, frivolous claims) and suggest possible ways to deal with them. ${ }^{229}$

Such a process would have to take into account that, apart from governments, a number of other stakeholders have a direct interest in the international investment regime and would need to be involved in the process. These include parliamentarians, the private sector, practitioners, trade unions, nonegovernmental organizations, academics, and representatives of international and regional intergovernmental organizations dealing with international investment. $^{230}$

The best option would be for one government (or, better yet, a few governments from developed and developing countries) or a respected non-governmental

228 It is encouraging in this respect that the Group of 7 , in its June 2014 Summit, had announced 'a new initiative on Strengthening Assistance for Complex Contract Negotiations (CONNEX) to provide developing country partners with extended and concrete expertise for negotiating complex commercial contracts, focusing initially on the extractives sector, and working with existing fora and facilities to avoid duplication'. See 'The Brussels G7 Summit Declaration', European Commission - MEMO/14/402 05/o6/. Independently of the establishment of such a facility, work on an online portal providing governments with information they need when negotiating large-scale contracts is being undertaken by the Columbia Center on Sustainable Investment at Columbia University see <http://www.vcc.columbia.edu/content/negotiation-support-developing-host-countries> accessed 15 September 2014.

Such a process could also encourage greater cooperation by the international organizations already working on investment (UNCTAD, OECD, ICSID, WTO, ASEAN).

230 And, of course, views differ within each of these groups of stakeholders. In the case of NGOs, for example, views range from those that seek an improvement of the regime, to those that seek to reorient its purpose fundamentally (especially toward giving central importance to sustainable development) to abolishing the investment regime altogether.

THE JOURNAL OF WORLD INVESTMENT \& TRADE 16 (2015) 11-87 
organization to initiate such an independent, open-minded, inclusive, informal, but structured, multi-stakeholder international investment consensus-building process - an incremental thought, discussion and confidence-building process on issues related to improving the international investment regime. The G2o could help initiate such a process by encouraging interested countries to launch it. One could even explore the possibility of having representatives from international organizations (informally?) service this process: after all, UNCTAD's Investment Division has continued UNCTC's substantial work on international investment agreements and, together with the OECD, ICSID, WTO, and ASEAN, has profound knowledge and understanding of this subject matter. In this context, it is a promising sign that Finland has begun consultations to launch such an initiative within the framework of the Helsinki Process for global governance that it chairs with Tanzania. ${ }^{231}$

The international investment regime is in constant flux, but its evolution does not follow a pre-ordained trajectory. ${ }^{232}$ It should be helpful that the positions of key stakeholders - host and home country governments, TNCs - have become less confrontational today than they were when the United Nations Code negotiations took place. However, the basic challenges that the Code negotiators faced remain, namely to bridge the basic interest situations of key stakeholders, to reconcile the application of national and international investment law governing foreign investment and to find the right balance between the rights and responsibilities of investors and governments. Improving the regime requires great efforts, a considerable amount of time and even more patience. And, above all, improvements in the international investment regime need to be in the interest of governments, both in their capacity as home and host countries, as well as other key stakeholders, to give it the legitimacy and robustness that every international regime requires to be viable in the long run. The experience gained during, and the lessons learned from, the negotiations of the United Nations Code should be of help in reaching this objective.

231 For information on the Helsinki Process, see <http://helsinkiprocess.fi/> accessed 15 September 2014. It should be recalled that an earlier phase of the Helsinki Process led to a major East-West agreement in the 1980 s, an agreement that few thought was possible at the beginning of the Process and that contributed to the profound changes that subsequently took place in Eastern Europe and the Soviet Union. This phase of the Helsinki Process is spurred by the implications of globalization.

232 On the evolution of the regime, see José E Alvarez and Karl P Sauvant, with Kamil Gerard Ahmed and Gabriela P Vizcaíno (eds), The Evolving International Investment Regime: Expectations, Realities, Options (OUP 2011).

THE JOURNAL OF WORLD INVESTMENT \& TRADE 16 (2015) 11-87 